\title{
ACPD
}

\section{Non-agricultural ammonia emissions in urban China}

\section{Y. H. Chang ${ }^{1,2}$}

${ }^{1}$ Department of Environmental Science and Engineering, Fudan University, Shanghai 200433, China

${ }^{2}$ Xinjiang Institute of Ecology and Geography, Chinese Academy of Sciences, Urumqi 830011, China

Received: 19 March 2014 - Accepted: 19 March 2014 - Published: 31 March 2014

Correspondence to: Y. H. Chang (changy13@fudan.edu.cn)

Published by Copernicus Publications on behalf of the European Geosciences Union.

\section{Non-agricultural ammonia emissions \\ in urban China \\ Y. H. Chang}

Title Page 


\section{Abstract}

The non-agricultural ammonia $\left(\mathrm{NH}_{3}\right)$ emissions in cities have received little attention but could rival agricultural sources in term of the efficiency in PM formation. The starting point for finding credible solutions is to comprehensively establish a city-specific Non5 agricultural Ammonia Emission Inventory (NAEI) and identify the largest sources where efforts can be directed to deliver the largest impact. In this paper, I present a NAEI of 113 national key cities targeted on environmental protection in China in 2010, which for the first time covers $\mathrm{NH}_{3}$ emissions from pets, infants, smokers, green land, and household products. Results show that totally $210478 \mathrm{Mg}$, the $\mathrm{NH}_{3}$ emissions from traf10 fic, fuel combustion, waste disposal, pets, green land, human, and household products are $67671 \mathrm{Mg}, 56275 \mathrm{Mg}, 44289 \mathrm{Mg}, 23355 \mathrm{Mg}, 7509 \mathrm{Mg}, 7312 \mathrm{Mg}$, and $4069 \mathrm{Mg}$, respectively. The $\mathrm{NH}_{3}$ emission intensity from the municipal districts ranges from 0.08 to $3.13 \mathrm{Mg} \mathrm{km}^{-2} \mathrm{yr}^{-1}$, with a average of $0.84 \mathrm{Mg} \mathrm{km}^{-2} \mathrm{yr}^{-1}$. The high $\mathrm{NH}_{3}$ emission intensities in Beijing-Tianjin-Hebei region, Yangtze River Delta region and Pearl River Delta 15 region support the view that non-agricultural $\mathrm{NH}_{3}$ sources play a key role in city-scale $\mathrm{NH}_{3}$ emissions and thus have potentially important implications for secondary PM formation (ammonium-sulfate-nitrate system) in urban agglomeration of China. Therefore, in addition to current $\mathrm{SO}_{2}$ and $\mathrm{NO}_{\mathrm{x}}$ controls, China also needs to allocate more scientific, technical, and legal resources on controlling non-agricultural $\mathrm{NH}_{3}$ emissions in the 20 future.

\section{Introduction}

Ammonia $\left(\mathrm{NH}_{3}\right)$ is the most abundant atmospheric base with the ability to neutralize sulphuric and nitric acids (oxidation products of $\mathrm{SO}_{2}$ and $\mathrm{NO}_{\mathrm{x}}\left(\mathrm{NO}+\mathrm{NO}_{2}\right)$, respectively) to form secondary particulate matter (PM) with an aerodynamic diameter equal to or
ACPD

14, 8495-8531, 2014

Non-agricultural

\section{ammonia emissions}

in urban China

Y. H. Chang

Title Page

Abstract

Introduction

Conclusions

References

Tables

Figures

14

$\rightarrow$

4

Back

Close

Full Screen / Esc

Printer-friendly Version

Interactive Discussion and Pandis, 2012). Current ambient air quality standards in many developed coun- 
tries and some developing countries covered $\mathrm{PM}_{2.5}$ in the book because of its adverse effects on human health, including premature mortality, chronic bronchitis, hospital admissions, and asthma attacks (Dockery et al., 1993; Nel, 2005; Pope et al., 2002; van Donkelaar et al., 2010). $\mathrm{NH}_{3}, \mathrm{NO}_{\mathrm{x}}$ and $\mathrm{SO}_{2}$ emissions reduction is the key to lower am5 bient levels of $\mathrm{PM}_{2.5}$ (Megaritis et al., 2013; Pathak et al., 2009). Major world economies have targeted reducing $\mathrm{NO}_{\mathrm{x}}$ and $\mathrm{SO}_{2}$ emissions. However, there are no regional emission ceilings set for $\mathrm{NH}_{3}$ (with the exception of the EU27 levels for European countries arising from the Gothenburg protocol, Reis et al., 2012) despite the fact that control technologies are cost-effective compared to $\mathrm{NO}_{x}$ and $\mathrm{SO}_{2}$ (Pinder et al., 2007). China 10 has over-fulfilled the national goal of a $10 \%$ reduction in $\mathrm{SO}_{2}$ emissions from 2005 to 2010 by $14.3 \%$, and $\mathrm{NO}_{\mathrm{x}}$ emissions are planned to be cut by $10 \%$ during the 12 th Five-Year Plan (2011-2015). Therefore, $\mathrm{NH}_{3}$ is expected to play an increased role in $\mathrm{PM}_{2.5}$ formation during the coming years (Chang et al., 2012).

It is well known that agricultural sources, notably animal manure and fertilizer ap15 plication, contribute the most to $\mathrm{NH}_{3}$ emissions (Cui et al., 2013; B. Gu et al., 2012). However, researchers have found that there are a myriad of important but frequently overlooked anthropogenic non-agricultural activities (e.g., vehicles and landfill) contributing to $\mathrm{NH}_{3}$ emissions (Battye et al., 2003; Pierson and Brachaczek, 1983; Sutton et al., 2000, 2008; Wilson et al., 2004), and many countries do not report emissions for all these terms. In the UK, the non-agricultural emissions of $\mathrm{NH}_{3}$ accounts for around $15 \%$ of the total national $\mathrm{NH}_{3}$ emissions, in which the transport sector is the main source (16\%), followed by sewage emissions (12\%) (Dragosits et al., 2008; Sutton et al., 2000). This clearly indicates that the emissions and sources of $\mathrm{NH}_{3}$ deserve a more comprehensive discussion in scientific community. Although compared to dominant agricultural $\mathrm{NH}_{3}$ source sectors such as livestock operations, these nonagricultural sources form a small part of the global $\mathrm{NH}_{3}$ emissions (Bouwman et al., 1997), and they might be more locally concentrated, particularly at an urban level. Moreover, those strong rural $\mathrm{NH}_{3}$ emissions can hardly make a long-range transport in gaseous phase to influence urban areas unless reacting locally to form particulate $\mathrm{NH}_{4}^{+}$.
ACPD

14, 8495-8531, 2014

Non-agricultural

ammonia emissions

in urban China

Y. H. Chang

Title Page
Abstract

Conclusions

Tables

14

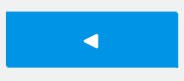

Back
Introduction

References

Figures

DI

Close
Full Screen / Esc

Printer-friendly Version

Interactive Discussion 
The non-agricultural $\mathrm{NH}_{3}$ emissions in an urban $\mathrm{SO}_{2}-$ and $\mathrm{NO}_{\mathrm{x}}$-rich atmosphere can be fully neutralized (Behera and Sharma, 2010; X. Huang et al., 2011), while model results showed that over half of $\mathrm{NH}_{3}$ emissions would be deposited downwind of its source within $10 \mathrm{~km}$ depending on local meteorological conditions. Meanwhile, the re5 maining part of $\mathrm{NH}_{3}$ in rural areas has less chance to convert to particulate $\mathrm{NH}_{4}^{+}$(Asman et al., 1998). Various studies worldwide suggest that the ambient levels of $\mathrm{NH}_{3}$ concentration in urban areas are comparable with, or even higher than that of rural areas (Doyle et al., 1979; Cadle et al., 1982; Allen et al., 1989, 2011; Giroux et al., 1997; Perrino et al., 2002; Burgard et al., 2006; Li et al., 2006; Whitehead et al., 2007; Alebic10 Juretic, 2008; Cao et al., 2009; Shen et al., 2009; Tanner, 2009; Behera and Sharma, 2010; Bishop et al., 2010; lanniello et al., 2010; Gong et al., 2011; Meng et al., 2011; Pandolfi et al., 2012; Reche et al., 2012; Ye et al., 2011; Zbieranowski and Aherne, 2012). In addition, the high seasonal variability of agricultural activities in rural areas tends to make pulse emissions of $\mathrm{NH}_{3}$, but the situation is much better for the case of 15 non-agricultural activities. These evidences mentioned above supporting a hypothesis that the non-agricultural $\mathrm{NH}_{3}$ emissions contribute to $\mathrm{PM}_{2.5}$ formation in urban areas may outweigh the contribution of agricultural $\mathrm{NH}_{3}$ emissions in a scale of a full year.

China, historically a nation of mostly agriculture activity, is in the vanguard of a wave of urban expansion that is driving the country towards an economic superpower. In the course of intense expansion, China urbanized nearly half of its people in 2010 (49.95\%) compared with $20 \%$ in 1980 (Gong et al., 2012). Beijing, for example, with over 10 million migrant workers and a similar size of local citizens already, is a living experiment in urbanization - and one that is failing to shine largely because of its severe air pollution (Watt, 2005; Zhang et al., 2012). In fact, alarm about the perilous state of $\mathrm{PM}_{2.5}$ pollution in Beijing has provoked a huge amount of public outcry and media attention lately (Chang, 2012). Beijing is however by no means unusual in today's China, it is over $50 \%$ cities in China have serious air pollution, and more than $75 \%$ of the urban population are exposed to high concentrations of both primary and secondary PM that does not meet the Chinese NAAQS (national ambient air quality standards)

\section{ACPD}

14, 8495-8531, 2014

\section{Non-agricultural ammonia emissions \\ in urban China \\ Y. H. Chang}

Title Page

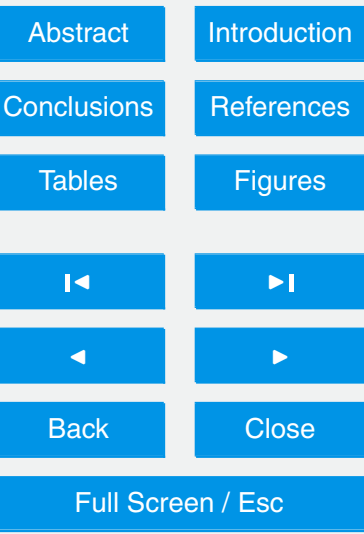

Printer-friendly Version

Interactive Discussion 
(Shao et al., 2006). Over the past several years, China has implemented a portfolio of plans to run more on-road vehicles with renewable energy, phase out its coal-fired power plants, and raise standards for auto emissions (Chang et al., 2012). If all goes to plan, China could expect a substantial emission reduction of $\mathrm{PM}_{2.5}$ and its precursors 5 (mainly $\mathrm{NO}_{x}$ and $\mathrm{SO}_{2}$ ) in the coming years. However, current benefits might be partially offset in the absence of the non-agricultural $\mathrm{NH}_{3}$ control (Chang et al., 2012).

An inventory of $\mathrm{NH}_{3}$ emission can serve as a baseline toward tracking emission trends, developing mitigation strategies, and assessing progress. Besides, it is necessary to provide detailed inventories combined with spatial mapping of emissions as inputs to atmospheric transport models. It has been estimated that the global $\mathrm{NH}_{3}$ emission was about $54 \mathrm{Tg}$ in 1990, $70 \%$ of which was related to food production (Olivier et al., 1998; Pinder et al., 2007). There are currently over 10 national emission inventories of $\mathrm{NH}_{3}$ in China (Sun and Wang, 1997; Wang et al., 1997, 2009; Klimont et al., 2001; Streets et al., 2003; FRCGC, 2007; Dong et al., 2010; Cao et al., 2011; B. Gu

et al., 2012; Huang et al., 2012; Li and Li, 2012; Cui et al., 2013), which providing strong evidence that China has experienced a dramatic increase of $\mathrm{NH}_{3}$ since the late 1970s (Fig. S1). Several regions with dense population such as the North China Plain (Zhang et al., 2010; Zhao et al., 2012), the Yangtze River Delta (Fu, 2009; C. Huang et al., 2011) and the Pearl River Delta (Yin et al., 2012; Zheng et al., 2012) are the $\mathrm{NH}_{3}$ hotspots. However, previous studies were mainly focused on the agricultural sector with large scales, such as global, Asian, national and regional inventories. As few studies involved transportation, waste disposal, human breath and sweat, etc. (Cao et al., 2011; Huang et al., 2012; Zheng et al., 2012), an inventory of city-scale $\mathrm{NH}_{3}$ emissions covering all non-agricultural sources is clearly missing. As a consequence, past endeavours have failed to adequately reflect the overall $\mathrm{NH}_{3}$ emissions status for individual cities, and failed to identify all the sources and activities that are responsible for $\mathrm{NH}_{3}$ emissions, subsequently hindering target setting for future management or abatement.
ACPD

14, 8495-8531, 2014

Non-agricultural

ammonia emissions

in urban China

Y. H. Chang

Title Page
Abstract

Conclusions

Tables

14

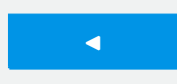

Back
Introduction

References

Figures

$\rightarrow 1$

Close
Full Screen / Esc

Printer-friendly Version

Interactive Discussion 
In this paper, I develop a comprehensive non-agricultural $\mathrm{NH}_{3}$ inventory for $113 \mathrm{Chi}$ nese cities based on statistical data in the year 2010. The emission sources included seven main categories, with each main category including several subcategories (Table 1). The activity data is based on province- or city-specific statistical data sets, with 5 the exception of the population of pets, which was deduced from urban residents according to a constant proportion. The emission factors (EFs) were derived from a wide range of literature, some of which have been revised to be more representative of the situation in China.

\section{Materials and method}

\subsection{Domain of the study}

The Ministry of Environmental Protection of China (MEP) selected 113 key "cities" for environmental protection since 2003 , and their daily concentrations of $\mathrm{PM}_{10}, \mathrm{SO}_{2}$, and $\mathrm{NO}_{2}$ are published on the MEP official website (http://datacenter.mep.gov.cn/). The 113 big cities are selected in terms of both population and economy, and the administrative area of these cities is at or above the prefecture level. In addition to their administrative centres in the urban districts, much of the administrative areas (e.g., counties) are rural. Therefore, it is not appropriate to select the entire administrative area since the assessment of non-agricultural activities is merely on the urban area. In this sense, the municipal district areas of the 113 cities were chosen as the domain of current study (Fig. 1). In 2010, the 113 cities totally accounted for $2.6 \%\left(250600 \mathrm{~km}^{2}\right), 17.4 \%$ (238 million), 39.8\% (15827 billion RMB) of China's land area, population and GDP, respectively. Table $\mathrm{S} 1$ presents detailed information regarding the social and economic index for each city.

\section{ACPD}

14, 8495-8531, 2014

Non-agricultural ammonia emissions

in urban China

Y. H. Chang

\section{Title Page}

Abstract

Conclusions

Tables

14

4

Back
Introduction

References

Figures

$\rightarrow 1$

Close
Full Screen / Esc

Printer-friendly Version

Interactive Discussion 


\subsection{Emission inventory estimate}

An emission inventory is generally calculated as a product of activity data and its corresponding emission factor. For the purposes of this study, the term "non-agricultural sources" excludes emissions from the agricultural sector (e.g., fertilizer application,

5 livestock operations), as well as natural sources (e.g., soils, wild animal populations). The primary census dataset was mostly obtained from several official yearbooks, which is currently the most authoritative data source in China. The main categories, subcategories and their representative EFs are listed in Table 1.

\subsubsection{Traffic}

10 The over-reduction of $\mathrm{NO}_{\mathrm{x}}$ by three-way catalytic converters (TWCs) in vehicles has been shown to produce $\mathrm{NH}_{3}$ in addition to $\mathrm{N}_{2}$ and water (Cadle et al., 1982; Fraser and Cass, 1998; Kean et al., 2000), and these are fitted to all newly manufactured light-duty vehicles in China (Huo et al., 2009). In 2009, China has surged past the United States to become the world's largest automobile market - including buses, 15 trucks and the small commercial vans that powered much of previous year's growth rose $46.2 \%$ to 13.6 million units. The $\mathrm{NH}_{3}$ emissions from vehicles for each city were calculated as the product of the number of operating vehicles, mileage and ammonia emissions per kilometre for each vehicle type. The original data on the provincial population of vehicles in 2010 were obtained from China Automotive Industry Yearbook 2011 (http://tongji.cnki.net/kns55/Navi/YearBook.aspx?id=N2011090109\&floor=1). In this work, these vehicles were divided into five different types, and the annual total mileages were based on previous work (Che et al., 2009). The EFs were quoted from the Emission Inventory Improvement Program (EIIP) database (Roe et al., 2004), which have been previously validated in the context of China (Huang et al., 2012; Zheng et al., 2012; Chao et al., 2014). Given that the important role of traffic to urban ammonia emissions, data like the composition of vehicle fleet, annual total mileages, and oil usages were also verified through various
ACPD

$14,8495-8531,2014$

Non-agricultural ammonia emissions

in urban China

Y. H. Chang

Title Page

Abstract

Introduction

Conclusions

References

Tables

Figures

14

- I

4

Back

Close

Full Screen / Esc

Printer-friendly Version

Interactive Discussion 
first-hand investigations. Although $\mathrm{NH}_{3}$ tailpipe emissions have been subject to a good deal of attention, the largest unknown is the ammonia emission factor for future catalyst systems. Recent technology has tried to reduce the effect (e.g., Tables 3-16 in http://www.eea.europa.eu/publications/emep-eea-guidebook-2013/ 5 part-b-sectoral-guidance-chapters/1-energy/1-a-combustion/1-a-3-b-road-transport). Thus, it is possible that ammonia emissions would decrease even further for new catalysts.

\subsubsection{Waste treatment}

Although the municipal waste treatment such as sewage treatment, landfill, compost and incineration of solid waste are known to emit $\mathrm{NH}_{3}$, the EFs of them are highly uncertain. For example, the $\mathrm{NH}_{3}$ EFs of wastewater treatment used in existing inventories vary widely, ranging over several orders of magnitude (Table S3).

Using the relative high EF $\left(1.93 \mathrm{~g} \mathrm{~m}^{-3}\right)$, two research teams provided independent emissions estimates for wastewater treatment in their recent inventories of $\mathrm{NH}_{3}$ emissions for the Pearl River Delta region (Zheng et al., 2012) and the entire China (Huang et al., 2012), respectively. An intensive investigation of $\mathrm{NH}_{3} \mathrm{EFs}$ for municipal wastewater treatment in China has been conducted in a more recent study, and this study adopted their result $\left(0.28 \mathrm{~g} \mathrm{NH}_{3} \mathrm{~m}^{-3}\right)$ in this study (Y. Gu et al., 2012). But then again, one thing should be noted is that using the highest factor to calculate emissions from wastewater treatment still produced an insignificant amount of $\mathrm{NH}_{3}$ emissions comparing to agricultural sources.

\subsubsection{Humans}

The proportion of Chinese living in urban areas is close to $50 \%$ mark in 2010 (49.95\%), yet this story overlooks China's special Hukou or household registration system, which may affect the real population living in urban/rural areas. This system divides the population into two types, agricultural and non-agricultural, under which peasants are strin-
ACPD

14, 8495-8531, 2014

Non-agricultural ammonia emissions

in urban China

Y. H. Chang

Title Page

Abstract

Introduction

Conclusions

References

Tables

Figures

14

$\rightarrow 1$

4 
gently barred from acquiring an urban registration even though they are allowed to go and work in the city. In 2010, nearly 460 million out of 666 million Chinese urban dwellers had urban registration status (Chan, 2012). The remaining 206 million "floating population", mostly migrant workers (130 million) who seek opportunities in 5 manufacturing centres such as Guangdong and Shanghai, are far less likely to receive pensions, basic health care, and unemployment insurance (Chan, 2012). In brief, there are three different types of population in urban China: resident population, registered population and migrant population.

Human metabolic processes such as respiration, perspiration and excretion can emit $10 \mathrm{NH}_{3}$ directly (Lee and Dollard, 1994). In rural China, human excrement is an important ammonia emitter. However, this source was not considered in the current study due to the popularity of flush toilets in urban areas, which means that the resident population waste was discharged into the sewage system instead of being returned to the soil. However, it is noted that the feces and urine in infant nappies do not enter the sewage 15 system and need to be taken into account. The 2010 infant population is the product of the registered population and the birth rate in this year. I calculated human $\mathrm{NH}_{3}$ emissions of human sweat and breathe by multiplying the resident population and the individual EF. The infant population is the product of the registered population and the birth rate. The $\mathrm{NH}_{3}$ EFs from infant nappies, human sweat and breath were taken from Sutton et al. (2000).

Cigarette smoking has been proved as a minor source of $\mathrm{NH}_{3}$. China continues to be the largest producer and consumer of tobacco worldwide. In 2010, an estimated $28.1 \%$ of adults (301 million people with age $\geq 15$ years) in China, $26.1 \%$ in urban areas (refers to the registered population here) and $29.8 \%$ in rural areas (refers to the migrant population here) (Li et al., 2011). Of all current smokers, $85.6 \%$ smoked daily. Smokers in China consumed an average of 14.2 cigarettes per day, which is comparable with that in the UK (16 and 14 cigarettes for men and women in 2005, respectively) (Li et al., 2011). The EF for smoking was also taken from Sutton et al. (2000).

\section{ACPD}

14, 8495-8531, 2014

Non-agricultural ammonia emissions

in urban China

Y. H. Chang

Title Page
Abstract

Conclusions

Tables

14

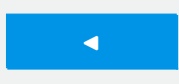

Back
Introduction

References

Figures

$\rightarrow 1$

$>$

Close
Full Screen / Esc

Printer-friendly Version

Interactive Discussion 


\subsubsection{Fuel combustion}

The USEPA developed the Emissions Inventory Improvement Program (EIIP) guidance for estimating $\mathrm{NH}_{3}$ emissions from industrial sources, combustion sources, and miscellaneous sources (Roe et al., 2004). Zheng et al. (2012) introduced EIIP in developing $5 \mathrm{a} \mathrm{NH}_{3}$ emissions inventory including domestic, power plant, and industrial fuel combustion sources in the Pearl River Delta region. Ruling out the traffic fuel consumption, the current inventory of fuel combustion sources is in accordance with the work done by Zheng et al. (2012).

\subsubsection{Urban land cover}

Little information is available on $\mathrm{NH}_{3}$ emissions from urban green land. However, green land, especially artificial grassland in urban areas needs nitrogen fertilizer to sustain it. In China, according to a report, an average of $200 \mathrm{~kg} \mathrm{Nha}^{-1} \mathrm{yr}^{-1}$ been applied in urban grassland (Zhang, 2002). In addition, a previous study recommended a volatilization rate of $2.5 \% \mathrm{NH}_{3}-\mathrm{N}$ of applied $\mathrm{N}$ (Sutton et al., 2000). When combined 15 with the $2.5 \% \mathrm{NH}_{3}-\mathrm{N}$ loss and $200 \mathrm{~kg} \mathrm{~N}$ for grassland fertilizer use, an annual $\mathrm{NH}_{3}$ EF of $6.1 \mathrm{kgNH}_{3} \mathrm{ha}^{-1} \mathrm{yr}^{-1}$ was obtained for China's urban grassland. The data of urban grassland were from China's City Yearbook 2011 (http://tongji.cnki.net/kns55/Navi/ YearBook.aspx?id=N2012020070\&floor=1).

Although still recognized as a luxury sport by most Chinese people, at present, there 20 is a growing popularity for playing golf in China. The turf grass of golf course typically needs $200-400 \mathrm{kgNha}^{-1} \mathrm{yr}^{-1}$ as N fertilizer to achieve high performance (Wong et al., 1998, 2002; Zhang, 2002). In 2010 alone, there were 60 new golf facilities opened, expanding the total number of the golf facilities in the country to 395 (equivalent to 490 18-hole courses) (Wang, 2011). According to a survey, every 18-hole equivalent golf course in China had 56.8 ha turf grass on average to be maintenance; this was $43.3 \%$ larger than that of the US (Wang, 2011). Given that the turf grass data for each golf

Non-agricultural ammonia emissions

in urban China

Y. H. Chang

Title Page

Abstract

Introduction

Conclusions

Tables

References

Figures

14

$\rightarrow$

4

Back

Close 
course is not available, this work does not consider the contribution of golf grassland to $\mathrm{NH}_{3}$ emissions.

\subsubsection{Pets}

Keeping pets has become increasingly popular in China, especially in the cities where

5 a growing number of people live alone and find it comforting to have a pet at home. As the two most popular pets in China, over 200 million dogs and 100 million cats were raised in 2010 (Yang, 2010). In recent years, there have been problems with unscooped poop and prevalent rabies, so municipal governments in Beijing and Shanghai have therefore proposed a one-dog policy limiting families to one canine per household. Officials revealed that as of 2010 there were about 0.92 and 0.74 million dogs registered in Beijing and Shanghai, respectively, and another 0.5 and 0.6 million dogs that were unlicensed. Unlike dogs, cats do not require a license and their number in cities is currently unavailable. By one estimate there are 0.5 to 0.6 million cats in Beijing (Pets in China, 2011). Information on the population of pets in other cities is extremely sparse in China; however, pet statistics in Beijing and Shanghai, to a large extent, reflect the situation of other cities concerning ownership of pets. Emissions from pets were estimated assuming that for every twenty-four city registered residents in China three dogs $(1 / 8)$ and one cat (1/24) were owned (J.-F. Zhou, personal communication, a pet expert working at Gerson Lehrman Group, 2013). The $\mathrm{NH}_{3}$ EFs of pets were derived from

\subsubsection{Domestic activity}

Technically, the domestic sources include pet animal waste, human breath and sweat. In this work, the term "domestic sources" here refers merely to the use of household products and non-agricultural fertilizers. The EFs of these sources are taken from a re-
ACPD

14, 8495-8531, 2014

Non-agricultural

\section{ammonia emissions}

in urban China

Y. H. Chang

Title Page 
the studies in European and the US However, these EFs shown in Table 1 are thought to be reasonable for application in China until additional updated data are available.

\section{Results and discussion}

\subsection{Non-agricultural $\mathrm{NH}_{3}$ emission inventory in $\mathbf{2 0 1 0}$}

5 Using the methodology described above and the data collected, I evaluated the sourcebased non-agricultural $\mathrm{NH}_{3}$ emissions and their corresponding contributions (Fig. 2). Taking the 113 cities as a whole, the overall non-agricultural $\mathrm{NH}_{3}$ emissions in 2010 is estimated at $210478 \mathrm{Mg}$, which accounts for about $5 \%$ of the annual agricultural $\mathrm{NH}_{3}$ emissions in China. A nationwide inventory on the non-agricultural $\mathrm{NH}_{3}$ emission for all 10 sources/cities is beyond the scope of this paper, therefore, this share is only one-third as much as the UK (15\%), and also lower than that in the EU27 (7\%) (Reis et al., 2009) and the USA (9\%) (Aneja et al., 2001). In the case of emission sources, traffic sources were the highest-profile contributor, accounting for about $32.2 \%$ (67671 Mg). Fuel combustion, waste disposal, pets, green land, human and household products 15 were responsible for $26.7 \%(56275 \mathrm{Mg}), 21 \%(44289 \mathrm{Mg}), 11.1 \%(23355 \mathrm{Mg}), 3.6 \%$ $(7509 \mathrm{Mg}), 3.5 \%(7312 \mathrm{Mg})$ and $1.9 \%(4069 \mathrm{Mg})$ of the total non-agricultural $\mathrm{NH}_{3}$ emissions, respectively (Fig. 2a). It is evident that nearly $60 \%$ of $\mathrm{NH}_{3}$ emissions originated from traffic and fuel combustion, which can be explained by the large population of vehicles equipped with catalytic converters as well as high energy consumption density in urban China. A more obvious example might be the USA, where on-road traffic is second to livestock manure management and application of chemical fertilizers, comprising approximately $7 \%$ of the national $\mathrm{NH}_{3}$ emission inventory (Burgard et al., 2006; Reis et al., 2009). Without involving $\mathrm{NH}_{3}$ in China's auto emission standards, it is expected that the sharing of vehicular $\mathrm{NH}_{3}$ emissions in the nation's $\mathrm{NH}_{3}$ emis25 sion inventory will be increased steadily. In addition, as the first initial assessment of pets and green land in China, the result indicates that ignoring their contribution of
ACPD

14, 8495-8531, 2014

Non-agricultural ammonia emissions

in urban China

Y. H. Chang

Title Page
Abstract

Conclusions

Tables

14

4

Back 
$\mathrm{NH}_{3}$ emissions may lead to around a $15 \%$ underestimate of the total non-agricultural $\mathrm{NH}_{3}$ emissions. Totalling approximately $9.8 \mathrm{Tg}$ on the base year of 2006 , in which nonagricultural sources (chemical industry, waste disposal and traffic) jointly contributed over $4 \%$, Huang et al. (2012) provided an unparalleled high-resolution $(1 \mathrm{~km} \times 1 \mathrm{~km})$ $5 \mathrm{NH}_{3}$ emission inventory in China. However, Huang et al. (2012) excluded the contribution of fuel combustion, waste disposal, pets, humans, green land and household products, which are collectively responsible for $46.9 \%$ of the total urban $\mathrm{NH}_{3}$ emissions in current study.

A full and detailed inter-comparison of the non-agricultural $\mathrm{NH}_{3}$ emission inventory 10 on sectoral level in different cities is presented in Fig. $2 \mathrm{~b}$ and Table 2. As illustrated in Fig. 2, the overall amount and the contributing proportion of the seven categories for each city show quite different patterns, which reflect their own unique socioeconomic profile. Despite the large variations of the contributing proportion from one city to another, traffic, fuel combustion and waste disposal are consistently the majority of

the $47.3 \%$ to $93.1 \%$ of the non-agricultural $\mathrm{NH}_{3}$ emissions in most of these cities. It is estimated that the average $\mathrm{NH}_{3}$ footprint, i.e. the $\mathrm{NH}_{3}$ emission intensity, from all the municipal districts of the 113 cities reached $0.84 \mathrm{Mg} \mathrm{km}^{-2} \mathrm{yr}^{-1}$. This indicator to date has also been regarded in the previous studies, and is summarized in Table 1. In 2010, 67 and 8 out of the 113 cities exceeded the lower and upper limit of $\mathrm{NH}_{3}$ emission 20 intensity estimate $\left(0.7-2.3 \mathrm{Mg} \mathrm{km}^{-2} \mathrm{yr}^{-1}\right.$ ) from Manchester city centre, respectively (Table S2). Domestically, estimates of the non-agricultural $\mathrm{NH}_{3}$ emission intensity in this study are in line with those reported in Beijing, Shanghai and Nanjing (the provincial capital of Jiangsu), but significantly higher than that from Guangzhou (the provincial capital of Guangdong). The main reason for the estimated gap is attributed to the use ent activity data, emission factors and base years used. Although the non-agricultural sources covered in this study are estimated to be a small contributor to the national annual inventories, Table 3 indicates that at a city scale, the percentage of the non-

\section{ACPD}

$14,8495-8531,2014$

Non-agricultural ammonia emissions

in urban China

Y. H. Chang

Title Page
Abstract

Conclusions

Tables

14

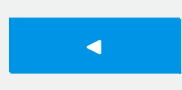

Back
Introduction

References

Figures

$>1$

Close
Full Screen / Esc

Printer-friendly Version

Interactive Discussion 
agricultural $\mathrm{NH}_{3}$ emissions to the agricultural $\mathrm{NH}_{3}$ emissions in Beijing and Shanghai could reach $27 \%, 43 \%$, respectively.

\subsection{Geographical distribution}

Figure 3 displays the spatial distributions of the 113 cities' non-agricultural $\mathrm{NH}_{3}$ emis5 sions for different emissions sources (Fig. 3a-g) and the total emissions (Fig. 3h). The spatial patterns of $\mathrm{NH}_{3}$ emission intensity can be found in Fig. 4. Generally, the spatial variability for all sources is in agreement with China's socioeconomic landscape, i.e., owing to a higher urbanization and larger population density in eastern and southern China, $\mathrm{NH}_{3}$ emissions from non-agricultural sources such as traffic, fuel combustion and others tend to be higher than those in the nation's remote northwest and southwest. Besides, Fig. 3e reveals that the bulk of urban green land emissions are contributed from the south, particularly in Guangzhou, Shanghai, Shenzhen and Chongqing, where there is a monsoon-influenced humid subtropical climate with abundant rainfall throughout the year. The favourable climate and fertile soil make south China known for its high plant diversity. In contrast, the fuel combustion from the longlived heating systems and energy-intensive industry amplifies the $\mathrm{NH}_{3}$ emissions in north China (Fig. 3b).

The atmospheric behaviour of $\mathrm{NH}_{3}$ characterized by short lifetime, near-source deposition, highly sensitive to meteorology and fast gas-to-particle conversion rate, highlights the need to improve $\mathrm{NH}_{3}$ emission estimate with fine temporal and spatial resolution (Behera and Sharma, 2010). Unlike the agricultural $\mathrm{NH}_{3}$ sources, the non-agricultural $\mathrm{NH}_{3}$ emissions originate from a variety of stationary sources (industrial coal/oil/gas combustion, wastewater, landfill, compost and incineration), mobile sources and area sources (e.g., humans, green land, domestic fuel combustion). Data such as the location/capacity/number of stationary sources are far from well documented in China. Therefore, a gridded emissions inventory of non-agricultural $\mathrm{NH}_{3}$ sources was not introduced in current work. The problem of data scarcity can be easily resolved for a city case study; however, it is nearly an impossible task for me to

Non-agricultural ammonia emissions in urban China

Y. H. Chang

Title Page 
collect all allocation-needed data for the 113 cities. Besides, given the city scale this work used, the spatial distribution of non-agricultural $\mathrm{NH}_{3}$ sources in any city cannot be distinguished on the map of China. Nevertheless, those results based on city-scale datasets are still valuable for chemical transport modellers who focus on a specific 5 Chinese city.

\subsection{Uncertainties of the inventory}

Ammonia emission inventories have inherent uncertainties because they associated with both the activity data and the emission factors used. For this inventory, activity data were mostly from statistical information. Although some question census data in Chinese statistical yearbooks are manipulated, with a tendency for officials to overstate economic outcome. However, compared with GDP data, the officials has less intention to manipulate the items that current work used. Therefore, the manipulation was not a serious issue during the study period and the data used in this study was credible. Nevertheless, the detailed pets and vehicle activity data (number of vehicles in each category, mileage, and oil usage of vehicles) was rarely collected and reported in China's statistics, which may introduce some uncertainties.

The EFs in current inventory are lack of the real physical and chemical examination. Moreover, the EFs show a substantial variation among different studies, and China has not established an adequate non-agricultural ammonia emission factors database 20 yet. Therefore, the major uncertainties of this inventory stem from the EFs this study used. Figure 5 illustrates the lower, the best and the upper estimates for the seven non-agricultural ammonia sources of the 113 key cities, respectively. The lower and the upper estimates are derived from the lowest and the highest EFs available in the published literature (Table S3). The overall estimated emission range was $140421-$ 25 $336811 \mathrm{Mgyr}^{-1}$, corresponding to the uncertainties of $-33-60 \%$. In terms of the potential change in mass of ammonia emissions over the entire domain, the uncertainty for traffic and fuel combustion represents 38475 and $38438 \mathrm{MgNH}_{3} \mathrm{yr}^{-1}$. From a stand-
ACPD

$14,8495-8531,2014$

Non-agricultural

ammonia emissions

in urban China

Y. H. Chang

Title Page 
point of variability, the humans and domestic activity category represents one of the most important sources of uncertainty.

A better characterization of the timing of climate-dependence non-agricultural $\mathrm{NH}_{3}$ sources, such as humans, pets, and urban land cover could be expected to reduce the 5 uncertainty of seasonal $\mathrm{NH}_{3}$ emissions estimates. However, these three sources contribute less than $10 \%$ of the total non-agricultural $\mathrm{NH}_{3}$ emissions. Moreover, it is easy to understand that the range of variation for dominant non-agricultural $\mathrm{NH}_{3}$ sources, such as traffic and fuel combustion, is much lower than agricultural $\mathrm{NH}_{3}$ sources (e.g., fertilizer application, livestock operations). Therefore, the seasonal differences of nonagricultural $\mathrm{NH}_{3}$ emission inventory are not been given in current work.

\subsection{Future recommendation and outlook}

China is now facing the world's worst air quality in terms of $\mathrm{PM}_{2.5}$ and its precursors (e.g., $\mathrm{SO}_{2}, \mathrm{NO}_{\mathrm{x}}$ and $\mathrm{NH}_{3}$ ) pollution. Some control measures such as upgrading motor vehicle emission standards to the China National Standard IV or higher, switching vehicle fuel to lower sulfur levels of gasoline in urban areas had been implemented in order to achieve a significant reduction in $\mathrm{NO}_{\mathrm{x}}$ and $\mathrm{SO}_{2}$ emissions. However, in Europe, based on a source-attribution simulation work, Megaritis et al. (2013) revealed that the reduction of $\mathrm{NH}_{3}$ emissions was the most cost-effective control strategy for reducing $\mathrm{PM}_{2.5}$ in both winter and summer. Besides, in the eastern United States, 20 Pinder et al. (2007) conducted a series of PMCAMx simulations and found many currently available $\mathrm{NH}_{3}$ control technologies were cost-effective compared to $\mathrm{SO}_{2}$ and $\mathrm{NO}_{\mathrm{x}}$. In China, using response surface modeling technique, Wang et al. (2011) suggested that the $90 \%$ increase of $\mathrm{NH}_{3}$ emissions during 1990-2005 resulted in nearly $50-60 \%$ increases of $\mathrm{NO}_{3}^{-}$and $\mathrm{SO}_{4}^{2-}$ aerosol concentrations in East China. Furthermore, Wang et al. (2013) used GEOS-Chem to investigate the influence of precursor emission changes on SNA aerosols concentration changes from 2000 to 2015, finding that the benefit of $\mathrm{SO}_{2}$ reduction would be completely offset if $\mathrm{NH}_{3}$ emissions were allowed to keep their recent growth rate over China. China's national annual total $\mathrm{NH}_{3}$

\section{ACPD}

$14,8495-8531,2014$

Non-agricultural ammonia emissions

in urban China

Y. H. Chang

Title Page

Abstract

Conclusions

References

Tables

Figures

14

$\rightarrow 1$

4

Back

Close

Full Screen / Esc

Printer-friendly Version

Interactive Discussion 
emissions account for around $30 \%$ and, $16 \%$ of total Asia, and global $\mathrm{NH}_{3}$ emissions, respectively. Obviously, in addition to current $\mathrm{SO}_{2}$ and $\mathrm{NO}_{\mathrm{x}}$ controls, China needs to put more scientific, technical, and legal attention on controlling $\mathrm{NH}_{3}$ emissions.

Most experimental studies and inventory-based assessment of $\mathrm{NH}_{3}$ emissions has 5 been and is being given to agricultural and natural sources (Liu et al., 2013; Paulot and Jacob, 2014). Compared to dominant agricultural sources of $\mathrm{NH}_{3}$ emissions, the nonagricultural sources covered in this study are estimated to contribute small amounts to national annual total $\mathrm{NH}_{3}$ emissions inventory. However, a diverse range of nonagricultural sources, such as on-road traffic and waste treatment could expect to domi10 nate in an urban domain, where agricultural sector contributions are relatively small. Existing $\mathrm{NH}_{3}$ emissions inventories do not include emission estimates for all nonagricultural sources included in this study, thus significantly underestimate the $\mathrm{NH}_{3}$ emissions in urbanized areas. Here I suggest that China should improve the understanding of current $\mathrm{NH}_{3}$ emission estimate and put more eyes on controlling nonagricultural sources of $\mathrm{NH}_{3}$ emissions in the future.

The efficiency of $\mathrm{NH}_{3}$ emissions in producing inorganic aerosol is highly non-linear and may vary from urban area to urban area. This work still falls short of providing an answer to how much of ammonium salts in the urban areas derives from nonagricultural vs. agricultural $\mathrm{NH}_{3}$ emissions, and how sensitive urban $\mathrm{PM}$ levels is to changes in local emissions. Therefore, it could be useful to run some source-receptor matrices (data from many model simulations and each of which reduces a different source of emissions) incorporating with the improved emission estimates in the vicinity of different Chinese cities to test the efficiency factors of different ammonia sources on particulate formation.

The use of three-way catalytic converters to reduce emissions of $\mathrm{NO}$ is considered to be an important factor in attaining present and future vehicle emissions standards and air quality goals. However, an unwanted side effect has been an increase in $\mathrm{NH}_{3}$ emissions. Until recently, motor vehicles were not recognized to be a significant source of $\mathrm{NH}_{3}$. In this paper, it is clear that the traffic sectors, especially the light-duty gasoline

\section{ACPD}

14, 8495-8531, 2014

Non-agricultural

ammonia emissions

in urban China

Y. H. Chang

Title Page
Abstract

Conclusions

Tables

14

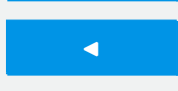

Back

\section{Introduction}

References

Figures

$\rightarrow 1$

$>$

Close
Full Screen / Esc

Printer-friendly Version

Interactive Discussion 
vehicles in urban China are a major source of $\mathrm{NH}_{3}$ emissions compared to the other non-agricultural sources. Therefore, future $\mathrm{NH}_{3}$ control efforts in urban China should prioritize the traffic sector, and this is especially true for China's top three city clusters, i.e., Beijing-Tianjin-Hebei region, the Yangtze Delta region, and the Pearl River Delta 5 region. $\mathrm{NH}_{3}$ generation from petrol-engined vehicles is primarily catalyzed by platinum. The capacity for $\mathrm{NH}_{3}$ generation can be modified by changing the catalyst or combination of catalysts used, though there are inevitably compromises to be reached given that performance has to be measured against a range of different pollutants (Handley et al., 2001). For the other sources, it is assumed that there are no reasonable op10 tions for controlling ammonia emissions from pets, human sweat and breath, cigarette smoking and nappies.

Because $\mathrm{NH}_{3}$ is not currently included as a criteria air pollutant in China and there are no government announced daily $\mathrm{NH}_{3}$ monitoring data, which limited the ability to validate the accuracy of emission inventory. The lack of monitoring data also emphasizes the need for publicly available comprehensive information systems in order to support the environmental evaluation of non-agricultural $\mathrm{NH}_{3}$ in urban China. Besides, some EFs derived from foreign studies would imply a significant uncertainty between different cities across China, which is challenging to validate and interpret. A recommendation is that the emission inventory for non-agricultural $\mathrm{NH}_{3}$ in China should be

\section{Summary}

In this work, I presented a comprehensive non-agricultural $\mathrm{NH}_{3}$ emission inventory for 113 Chinese cities. This work illustrates the possible under-estimation of $\mathrm{NH}_{3}$ in some inventories, and can be expected to initiate wider discussion on methodologies for es-

\section{ACPD}

$14,8495-8531,2014$

Non-agricultural ammonia emissions

in urban China

Y. H. Chang

Title Page
$>$

lose 
providing the basis for policy makers to determine how to prioritize future control efforts among different non-agricultural sources of $\mathrm{NH}_{3}$ emissions in urban China.

\section{Supplementary material related to this article is available online at http://www.atmos-chem-phys-discuss.net/14/8495/2014/ 5 acpd-14-8495-2014-supplement.pdf.}

Acknowledgements. This work was supported financially by the West Light Foundation of the Chinese Academy of Sciences (XBBS201206), the Major State Basic Research Development Program of China (Nos. 2014CB954200-02), National Natural Science Foundation of China (21377029). I thank Xuejun Liu (CAU, China), Congrui Deng (Fudan, China), Tony Dore (CEH, 10 UK) and Peter Christie (Belfast, UK) for their constructive comments and linguistic corrections. The views expressed in this paper are those of the author's and do not necessarily reflect the views of Fudan University and Chinese Academy of Sciences.

\section{References}

Alebic-Juretic, A.: Airborne ammonia and ammonium within the Northern Adriatic area, Croatia, Environ. Pollut., 154, 439-447, 2008.

Allen, A., Harrison, R. M., and Erisman, J. W.: Field measurements of the dissociation of ammonium nitrate and ammonium chloride aerosols, Atmos. Environ., 23, 1591-1599, 1989.

Allen, R., Myles, L., and Heuer, M. W.: Ambient ammonia in terrestrial ecosystems: a comparative study in the Tennessee Valley, USA, Sci. Total Environ., 409, 2768-2772, 2011.

20 Aneja, V. P., Roelle, P. A., Murray, G. C., Southerland, J., Erisman, J. W., Fowler, D., Asman, W. A. H., and Patni, N.: Atmospheric nitrogen compounds II: emissions, transport, transformation, deposition and assessment, Atmos. Environ., 35, 1903-1911, 2001.

Asman, W. A. H., Sutton, M. A., and Schjorring, J. K.: Ammonia: emission, atmospheric transport and deposition, New Phytol., 139, 27-48, 1998.

Battye, W., Aneja, V. P., and Roelle, P. A.: Evaluation and improvement of ammonia emissions inventories, Atmos. Environ., 37, 3873-3883, 2003.

\section{ACPD}

14, 8495-8531, 2014

Non-agricultural

ammonia emissions

in urban China

Y. H. Chang

Title Page 
Behera, S. N. and Sharma, M.: Investigating the potential role of ammonia in ion chemistry of fine particulate matter formation for an urban environment, Sci. Total Environ., 408, 35693575, 2010.

Bishop, G. A., Peddle, A. M., Stedman, D. H., and Zhan, T.: On-road emission measurements of reactive nitrogen compounds from three California cities, Environ. Sci. Technol., 44, 36163620, 2010.

Bouwman, A. F., Lee, D. S., Asman, W. A. H., Dentener, F. J., Van der Hoek, K. W., and Olivier, J. G. J.: A global high-resolution emission inventory for ammonia, Global Biogeochem. Cy., 11, 561-587, 1997.

10 Burgard, D. A., Bishop, G. A., and Stedman, D. H.: Remote sensing of ammonia and sulfur dioxide from on-road light duty vehicles, Environ. Sci. Technol., 40, 7018-7022, 2006.

Cadle, S., Countess, R., and Kelly, N.: Nitric acid and ammonia in urban and rural locations, Atmos. Environ., 16, 2501-2506, 1982.

Cao, G., Zhang, X., Gong, S., An, X., and Wang, Y.: Emission inventories of primary particles 15

Cao, J. J., Zhang, T., Chow, J. C., Watson, J. G., Wu, F., and Li, H.: Characterization of atmospheric ammonia over Xi'an, China, Aerosol Air Qual. Res., 9, 277-289, 2009.

Chan, K. W.: Crossing the 50 percent population rubicon: can China urbanize to prosperity?, Eurasian Geogr. Econ., 53, 63-86, 2012.

20 Chang, Y. H.: China needs a tighter $\mathrm{PM}_{2.5}$ limit and a change in priorities, Environ. Sci. Technol., 46, 7069-7070, 2012.

Chang, Y. H., Liu, X. J., Dore, A. J., and Li, K. H.: Stemming $\mathrm{PM}_{2.5}$ pollution in China: Reevaluating the role of ammonia, aviation and non-exhaust road traffic emissions, Environ. Sci. Technol., 46, 13035-13036, 2012.

Chao, N., Tang, G., Wang, Y., Wang, H., Huang, J., and Chen, J.: Vehicular emissions in China in 2006 and 2010, Atmos. Chem. Phys. Discuss., 14, 4905-4956, doi:10.5194/acpd14-4905-2014, 2014.

Che, W., Zheng, J., and Zhong, L.: Vehicle exhaust emission characteristics and contributions in the Pearl River Delta region, Res. Environ. Sci., 22, 456-461, 2009 (in Chinese with English abstract).

Cui, S., Shi, Y., Groffman, P. M., Schlesinger, W. H., and Zhu, Y. G.: Centennial-scale analysis of the creation and fate of reactive nitrogen in China (1910-2010), P. Natl. Acad. Sci. USA, 110, 2052-2057, 2013.

\section{ACPD}

14, 8495-8531, 2014

Non-agricultural

ammonia emissions

in urban China

Y. H. Chang

Title Page

Abstract

Introduction

Conclusions

References

Tables

Figures

14

$\rightarrow$

4

Back

$>$

Close

Full Screen / Esc

Printer-friendly Version

Interactive Discussion 
Dockery, D. W., Pope, C. A., Xu, X., Spengler, J. D., Ware, J. H., Fay, M. E., Ferris, B. G., and Speizer, F. E.: An association between air pollution and mortality in six US cities, New Engl. J. Med., 329, 1753-1759, 1993.

Dong, W. X., Xing, J., and Wang, S. X.: Temporal and spatial distribution of anthropogenic ammonia emissions in China: 1994-2006, Environ. Sci., 31, 1457-1463, 2010 (in Chinese with English abstract).

Dong, Y., Chen, C., Huang, C., Wang, H., Li, L., Dai, P., and Jia, J.: Anthropogenic emissions and distribution of ammonia over the Yangtze River Delta, Acta Scientiae Circumstantie, 29, 1611-1617, 2009 (in Chinese with English abstract).

10 Doyle, G. J., Tuazon, E. C., Graham, R. A., Mischke, T. M., Winer, A. M., and Pitts Jr., J. N.: Simultaneous concentrations of ammonia and nitric acid in a polluted atmosphere and their equilibrium relationship to particulate ammonium nitrate, Environ. Sci. Technol., 13, 14161419, 1979.

Dragosits, U., Dore, A., Sheppard, L., Vieno, M., Tang, Y., Follett, R., and Hatfield, J.: Sources, dispersion and fate of atmospheric ammonia, in: Nitrogen in the Environment: Sources, Problems, and Management, edited by: Hatfield, J. L. and Follett, R. F., Academic Press, Amsterdam, 333-393, 2008.

Fraser, M. P. and Cass, G. R.: Detection of excess ammonia emissions from in-use vehicles and the implications for fine particle control, Environ. Sci. Technol., 32, 1053-1057, 1998.

20

FRCGC (Regional Emission Inventory in Asia): available at: http://www.jamstec.go.jp/frsgc/ research/d4/emission.htm (last access: 2 February 2014), 2007.

Fu, Q. Y.: Air pollutant emission inventory in Shanghai and the formation mechanism of heavy fine particulate pollution episode, Ph.D. Dissertation, Fudan University, Shanghai, China, 2009.

Giroux, M., Esclassan, J., Arnaud, C., and Chale, J. J.: Analysis of levels of nitrates and derivatives of ammonia in an urban atmosphere, Sci. Total Environ., 196, 247-254, 1997.

Gong, L., Lewicki, R., Griffin, R. J., Flynn, J. H., Lefer, B. L., and Tittel, F. K.: Atmospheric ammonia measurements in Houston, TX using an external-cavity quantum cascade laserbased sensor, Atmos. Chem. Phys., 11, 9721-9733, doi:10.5194/acp-11-9721-2011, 2011.

30 Gong, P., Liang, S., Carlton, E. J., Jiang, Q., Wu, J., Wang, L., and Remais, J. V.: Urbanisation and health in China, Lancet, 379, 843-852, 2012.

\section{ACPD}

14, 8495-8531, 2014

Non-agricultural ammonia emissions

in urban China

Y. H. Chang

Title Page

Abstract

Conclusions

References

Tables

Figures

14

$\rightarrow 1$

4

Back

Close

Full Screen / Esc

Printer-friendly Version

Interactive Discussion 
Gu, B., Ge, Y., Ren, Y., Xu, B., Luo, W., Jiang, H., Gu, B., and Chang, J.: Atmospheric reactive nitrogen in China: sources, recent trends, and damage costs, Environ. Sci. Technol., 46, 9420-9427, 2012.

Gu, Y., Wang, B., Yang, J., and Zhong, S.: Ammonia source and emission factor in municipal 5 wastewater treatment plants, Environ. Chem., 31, 708-713, 2012 (in Chinese with English abstract).

Handley, C., Holland, M., and Dore, C.: Murrells, controlling ammonia from non-agricultural sources, AEAT technology report for DETR, AET/ENV/R/0565, AEA TechnologyAbingdon, Oxfordshire, UK, 2001.

10 Huang, C., Chen, C. H., Li, L., Cheng, Z., Wang, H. L., Huang, H. Y., Streets, D. G., Wang, Y. J., Zhang, G. F., and Chen, Y. R.: Emission inventory of anthropogenic air pollutants and VOC species in the Yangtze River Delta region, China, Atmos. Chem. Phys., 11, 4105-4120, doi:10.5194/acp-11-4105-2011, 2011.

Huang, X., Qiu, R., Chan, C. K., and Ravi Kant, P.: Evidence of high $\mathrm{PM}_{2.5}$ strong acidity in ammonia-rich atmosphere of Guangzhou, China: transition in pathways of ambient ammonia to form aerosol ammonium at $\left[\mathrm{NH}_{4}^{+}\right] /\left[\mathrm{SO}_{4}^{2-}\right]=1.5$, Atmos. Res., 99, 488-495, 2011.

Huang, X., Song, Y., Li, M. M., Li, J. F., Huo, Q., Cai, X. H., Zhu, T., Hu, M., and Zhang, H. S.: A high-resolution ammonia emission inventory in China, Global Biogeochem. Cy., 26, GB1030, doi:10.1029/2011GB004161, 2012.

20 Huo, H., Zhang, Q., He, K., Wang, Q., Yao, Z., and Streets, D. G.: High-resolution vehicular emission inventory using a link-based method: a case study of light-duty vehicles in Beijing, Environ. Sci. Technol., 43, 2394-2399, 2009.

Ianniello, A., Spataro, F., Esposito, G., Allegrini, I., Rantica, E., Ancora, M. P., Hu, M., and Zhu, T.: Occurrence of gas phase ammonia in the area of Beijing (China), Atmos. Chem. Phys., 10, 9487-9503, doi:10.5194/acp-10-9487-2010, 2010.

Kean, A. J., Harley, R. A., Littlejohn, D., and Kendall, G. R.: On-road measurement of ammonia and other motor vehicle exhaust emissions, Environ. Sci. Technol., 34, 3535-3539, 2000.

Klimont, Z., Cofala, J., Schöpp, W., Amann, M., Streets, D. G., Ichikawa, Y., and Fujita, S.: Projections of $\mathrm{SO}_{2}, \mathrm{NO}_{\mathrm{x}}, \mathrm{NH}_{3}$ and $\mathrm{VOC}$ emissions in East Asia up to 2030, Water Air Soil Pollut., 130, 193-198, 2001.

Lee, D. S. and Dollard, G. J.: Uncertainties in current estimates of emissions of ammonia in the UK, Environ. Pollut., 86, 267-277, 1994.
ACPD

14, 8495-8531, 2014

Non-agricultural

\section{ammonia emissions}

in urban China

Y. H. Chang

Title Page 
Li, Q., Hsia, J., and Yang, G. H.: Prevalence of smoking in China in 2010, New Engl. J. Med., 364, 2469-2470, 2011.

$\mathrm{Li}, \mathrm{X}$. Y. and Li, H. P.: Emission and distribution of $\mathrm{NH}_{3}$ and $\mathrm{NO}_{\mathrm{x}}$ in China, China Environ. Sci., 32, 37-42, 2012 (in Chinese with English abstract).

5 Li, Y. Q., Schwab, J. J., and Demerjian, K. L.: Measurements of ambient ammonia using a tunable diode laser absorption spectrometer: characteristics of ambient ammonia emissions in an urban area of New York City, J. Geophys. Res., 111, D10S02, doi:10.1029/2005JD006275, 2006.

Liu, X., Zhang, Y., Han, W., Tang, A., Shen, J., Cui, Z., Vitousek, P., Erisman, J. W., Goulding, K., Christie, P., Fangmeier, A., and Zhang, F.: Enhanced nitrogen deposition over China, Nature, 494, 459-462, 2013.

Megaritis, A. G., Fountoukis, C., Charalampidis, P. E., Pilinis, C., and Pandis, S. N.: Response of fine particulate matter concentrations to changes of emissions and temperature in Europe, Atmos. Chem. Phys., 13, 3423-3443, doi:10.5194/acp-13-3423-2013, 2013.

15 Meng, Z. Y., Lin, W. L., Jiang, X. M., Yan, P., Wang, Y., Zhang, Y. M., Jia, X. F., and Yu, X. L.: Characteristics of atmospheric ammonia over Beijing, China, Atmos. Chem. Phys., 11, 61396151, doi:10.5194/acp-11-6139-2011, 2011.

Nel, A.: Air pollution-related illness: effects of particles, Science, 308, 804-806, 2005.

Olivier, J. G. J., Bouwman, A. F., Van der Hoek, K. W., and Berdowski, J. J. M.: Global air emission inventories for anthropogenic sources of $\mathrm{NO}_{x}, \mathrm{NH}_{3}$ and $\mathrm{N}_{2} \mathrm{O}$ in 1990, Environ. Pollut., 102, 135-148, 1998.

Pandolfi, M., Amato, F., Reche, C., Alastuey, A., Otjes, R. P., Blom, M. J., and Querol, X.: Summer ammonia measurements in a densely populated Mediterranean city, Atmos. Chem. Phys., 12, 7557-7575, doi:10.5194/acp-12-7557-2012, 2012.

Pathak, R. K., Wu, W. S., and Wang, T.: Summertime $\mathrm{PM}_{2.5}$ ionic species in four major cities of China: nitrate formation in an ammonia-deficient atmosphere, Atmos. Chem. Phys., 9, 1711-1722, doi:10.5194/acp-9-1711-2009, 2009.

Paulot, F. and Jacob, D. J.: Hidden cost of US agricultural exports: particulate matter from ammonia emissions, Environ. Sci. Technol., 48, 903-908, doi:10.1021/es4034793, 2014.

so Perrino, C., Catrambone, M., Di Bucchianico, A. D. M., and Allegrini, I.: Gaseous ammonia in the urban area of Rome, Italy and its relationship with traffic emissions, Atmos. Environ., 36, 5385-5394, 2002.

\section{ACPD}

14, 8495-8531, 2014

Non-agricultural

ammonia emissions

in urban China

Y. H. Chang

Title Page

Abstract

Introduction

Conclusions

References

Tables

Figures

14

$\rightarrow 1$

4

Back

Close 
Pets in China: Cats, singing birds and goldfish, available at: http://factsanddetails.com/china/ cat12/sub81/item267.html\#chapter-1 (last access: 2 February 2014), 2011.

Pierson, W. R. and Brachaczek, W. W.: Emissions of ammonia and amines from vehicles on the road, Environ. Sci. Technol., 17, 757-760, 1983.

5 Pinder, R. W., Adams, P. J., and Pandis, S. N.: Ammonia emission controls as a cost-effective strategy for reducing atmospheric particulate matter in the eastern United States, Environ. Sci. Technol., 41, 380-386, 2007.

Pope, C. A., Burnett, R. T., Thun, M. J., Calle, E. E., Krewski, D., Ito, K., and Thurston, G. D.: Lung cancer, cardiopulmonary mortality, and long-term exposure to fine particulate air pollution, J. Am. Med. Assoc., 287, 1132-1141, 2002.

Reche, C., Viana, M., Pandolfi, M., Alastuey, A., Moreno, T., Amato, F., Ripoll, A., and Querol, X.: Urban $\mathrm{NH}_{3}$ levels and sources in a Mediterranean environment, Atmos. Environ., 57, 153164, 2012.

Reis, S., Pinder, R. W., Zhang, M., Lijie, G., and Sutton, M. A.: Reactive nitrogen in atmo15 spheric emission inventories, Atmos. Chem. Phys., 9, 7657-7677, doi:10.5194/acp-9-76572009, 2009.

Reis, S., Grennfelt, P., Klimont, Z., Amann, M., ApSimon, H., Hettelingh, J., Holland, M., LeGall, A., Maas, R., and Posch, M.: From acid rain to climate change, Science, 338, 11531154, 2012.

20 Roe, S. M., Spivey, M. D., Lindquist, H. C., Thesing, K. B., and Strait, R. P.: Estimating ammonia emissions from anthropogenic nonagricultural sources, Draft final report, US EPA, Research Triangle Park, NC, USA, 2004.

Seinfeld, J. H. and Pandis, S. N.: Atmospheric Chemistry and Physics: from Air Pollution to Climate Change, 2nd edn., John Wiley and Sons, Inc., Hoboken, NJ, 2006.

Shao, M., Tang, X. Y., Zhang, Y. H., and Li, W. J.: City clusters in China: air and surface water pollution, Front. Ecol. Environ., 4, 353-361, 2006.

Shen, J. L., Tang, A. H., Liu, X. J., Fangmeier, A., Goulding, K. T., and Zhang, F. S.: High concentrations and dry deposition of reactive nitrogen species at two sites in the North China Plain, Environ. Pollut., 157, 3106-3113, 2009.

30 Streets, D. G., Bond, T. C., Carmichael, G. R., Fernandes, S. D., Fu, Q., He, D., Klimont, Z., Nelson, S. M., Tsai, N. Y., Wang, M. Q., Woo, J. H., and Yarber, K. F.: An inventory of gaseous and primary aerosol emissions in Asia in the year 2000, J. Geophys. Res., 108, 8809, doi:10.1029/2002JD003093, 2003.

ACPD

14, 8495-8531, 2014

Non-agricultural

ammonia emissions

in urban China

Y. H. Chang

Title Page

Abstract

Introduction

Conclusions

References

Tables

Figures

14

- I

4

Back

$>$

Close

Full Screen / Esc

Printer-friendly Version

Interactive Discussion 
Sun, Q. and Wang, M.: Ammonia emission and concentration in the atmosphere over China, Scientia Atmospherica Sinica, 21, 590-598, 1997 (in Chinese with English abstract).

Sutton, M. A., Dragosits, U., Tang, Y. S., and Fowler, D.: Ammonia emissions from nonagricultural sources in the UK, Atmos. Environ., 34, 855-869, 2000.

5 Sutton, M. A., Erisman, J. W., Dentener, F., and Moller, D.: Ammonia in the environment: from ancient times to the present, Environ. Pollut., 156, 583-604, 2008.

Tanner, P. A.: Vehicle-related ammonia emissions in Hong Kong, Environ. Chem. Lett., 7, 3740, 2009.

van Donkelaar, A., Martin, R. V., Brauer, M., Kahn, R., Levy, R., Verduzco, C., and Villeneuve, P. J.: Global estimates of ambient fine particulate matter concentrations from satellite-based aerosol optical depth: development and application, Environ. Health Persp., 118, 847-855, 2010.

Wang, J.: China Golf Industry Report, Forward Group, Beijing, available at: http://www. forwardgolf.com.cn/electronic.asp (last access: 2 February 2014), 2011.

Wang, S. W., Liao, Q. J. H., Hu, Y. T., and Yan, X. Y.: A preliminary inventory of $\mathrm{NH}_{3}-\mathrm{N}$ emission and its temporal and spatial distribution of China, J. Agro-Environ. Sci., 28, 619-626, 2009 (in Chinese with English abstract).

Wang, S. X., Xing, J., Jang, C. R., Zhu, Y., Fu, J. S., and Hao, J. M.: Impact assessment of ammonia emissions on inorganic aerosols in East China using response surface modeling technique, Environ. Sci. Tech., 45, 9293-9300, 2011.

Wang, W. X., Lu, X. F., Pang, Y. B., Tang, D. G., and Zhang, W. H.: Geographical distribution of $\mathrm{NH}_{3}$ emission intensities in China, Acta Scientiae Circumstantiae, 17, 2-7, 1997 (in Chinese with English abstract).

Wang, Y., Zhang, Q. Q., He, K., Zhang, Q., and Chai, L.: Sulfate-nitrate-ammonium aerosols over China: response to 2000-2015 emission changes of sulfur dioxide, nitrogen oxides, and ammonia, Atmos. Chem. Phys., 13, 2635-2652, doi:10.5194/acp-13-2635-2013, 2013.

Watt, J.: China: the air pollution capital of the world, Lancet, 366, 1761-1762, 2005.

Whitehead, J. D., Longley, I. D., and Gallagher, M. W.: Seasonal and diurnal variation in atmospheric ammonia in an urban environment measured using a quantum cascade laser absorption spectrometer, Water Air Soil Pollut., 183, 317-329, 2007.

Wilson, L. J., Bacon, P. J., Bull, J., Dragosits, U., Blackall, T. D., Dunn, T. E., Hamer, K. C., Sutton, M. A., and Wanless, S.: Modelling the spatial distribution of ammonia emissions from seabirds in the UK, Environ. Pollut., 131, 173-185, 2004.

ACPD

14, 8495-8531, 2014

Non-agricultural

ammonia emissions

in urban China

Y. H. Chang

Title Page

Abstract

Introduction

Conclusions

References

Tables

Figures

14

$\rightarrow 1$

4

Back

Close

Full Screen / Esc

Printer-friendly Version

Interactive Discussion 
Wong, J., Chan, C., and Cheung, K.: Nitrogen and phosphorus leaching from fertilizer applied on golf course: lysimeter study, Water Air Soil Pollut., 107, 335-345, 1998.

Wong, J. W. C., Chan, C. W. Y., and Cheung, K. C.: Research progress about the impact of fertilizer and pesticide on the environment of golf course, Grassl. Turf, 4, 6-10, 2002 (in

5 Chinese with English abstract).

Yang, C.: Feline frenzy, available at: http://business.globaltimes.cn/comment/2010-10/580528. html (last access: 3 February 2014), Global Times, 2010.

Ye, X., Ma, Z., Zhang, J., Du, H., Chen, J., Chen, H., Yang, X., Gao, W., and Geng, F.: Important role of ammonia on haze formation in Shanghai, Environ. Res. Lett., 6, 024019, doi:10.1088/1748-9326/6/2/024019, 2011.

Yin, S. S., Zheng, J. Y., Zhang, L. J., and Zhong, L. J.: Anthropogenic ammonia emission inventory and characteristics in the Pearl River Delta region, Environ. Sci., 31, 1146-1151, 2012 (in Chinese with English abstract).

Zbieranowski, A. L. and Aherne, J.: Ambient concentrations of atmospheric ammonia, nitrogen dioxide and nitric acid across a rural-urban-agricultural transect in southern Ontario, Canada. Atmos. Environ., 62, 481-491, 2012.

Zhang, Q., He, K. B., and Huo, H.: Cleaning China's air, Nature, 484, 161-162, 2012.

Zhang, R. L.: Research advances on fertilizers application to lawn, Trop. Agric. Sci., 22, 77-81, 2002 (in Chinese with English abstract).

20 Zhang, Y., Dore, A. J., Ma, L., Liu, X. J., Ma, W. Q., Cape, J. N., and Zhang, F. S.: Agricultural ammonia emissions inventory and spatial distribution in the North China Plain, Environ. Pollut., 158, 490-501, 2010.

Zhao, B., Wang, P., Ma, J. Z., Zhu, S., Pozzer, A., and Li, W.: A high-resolution emission inventory of primary pollutants for the Huabei region, China, Atmos. Chem. Phys., 12, 481-501, doi:10.5194/acp-12-481-2012, 2012.

Zheng, J. Y., Yin, S. S., Kang, D. W., Che, W. W., and Zhong, L. J.: Development and uncertainty analysis of a high-resolution $\mathrm{NH}_{3}$ emissions inventory and its implications with precipitation over the Pearl River Delta region, China, Atmos. Chem. Phys., 12, 7041-7058, doi:10.5194/acp-12-7041-2012, 2012.

\section{ACPD}

14, 8495-8531, 2014

Non-agricultural

\section{ammonia emissions}

in urban China

Y. H. Chang

\section{Title Page}

\section{Abstract}

Introduction

Conclusions

References

Tables

Figures

14

$\rightarrow$

4

Back

Close

\section{Full Screen / Esc}

Printer-friendly Version

Interactive Discussion 
Table 1. Representative ammonia EFs of non-agricultural sources.

\begin{tabular}{|c|c|c|c|c|}
\hline Category & Subcategory & $\begin{array}{l}\text { Emission } \\
\text { factor }\end{array}$ & Unit (as $\mathrm{NH}_{3}$ ) & Reference \\
\hline \multirow[t]{5}{*}{ Traffic } & Light-duty gasoline vehicles & 63.20 & $\mathrm{mgkm}^{-1}$ & Roe et al. (2004) \\
\hline & Heavy-duty gasoline vehicles & 28.00 & $\mathrm{mgkm}^{-1}$ & Roe et al. (2004) \\
\hline & Light-duty diesel vehicles & 4.20 & $\mathrm{mgkm}^{-1}$ & Roe et al. (2004) \\
\hline & Heavy-duty diesel vehicles & 16.80 & $\mathrm{mgkm}^{-1}$ & Roe et al. (2004) \\
\hline & Motorcycles & 7.00 & $\mathrm{mg} \mathrm{km}^{-1}$ & Roe et al. (2004) \\
\hline \multirow{4}{*}{$\begin{array}{l}\text { Waste } \\
\text { treatment }\end{array}$} & Wastewater & 0.28 & $\mathrm{gm}^{-3}$ & Y. Gu et al. (2012) \\
\hline & Landfill & 0.56 & $\mathrm{kgt}^{-1}$ & Yin et al. (2012) \\
\hline & Compost & 1.28 & $\mathrm{kgt}^{-1}$ & Roe et al. (2004) \\
\hline & Incineration & 0.21 & $\mathrm{kgt}^{-1}$ & Yin et al. (2012) \\
\hline \multirow[t]{4}{*}{ Humans } & Human breath & 3.64 & gperson $^{-1} \mathrm{yr}^{-1}$ & Sutton et al. (2000) \\
\hline & Human sweat & 17.00 & gperson $^{-1} \mathrm{yr}^{-1}$ & Sutton et al. (2000) \\
\hline & Infants (0-3yr) & 16.64 & ginfant $^{-1} \mathrm{yr}^{-1}$ & Sutton et al. (2000) \\
\hline & Smoking & 21.61 & gsmoker $^{-1} \mathrm{yr}^{-1}$ & Sutton et al. (2000) \\
\hline \multirow{6}{*}{$\begin{array}{l}\text { Fuel } \\
\text { combustion }\end{array}$} & Industrial coal combustion & 0.02 & $\mathrm{kgt}^{-1}$ & Roe et al. (2004) \\
\hline & Domestic coal combustion & 0.90 & $\mathrm{kgt}^{-1}$ & Roe et al. (2004) \\
\hline & Industrial oil combustion & 0.10 & $\operatorname{kg}\left(10^{3} L\right)^{-1}$ & Roe et al. (2004) \\
\hline & Domestic oil combustion & 0.12 & $\operatorname{kg}\left(10^{3} \mathrm{~L}\right)^{-1}$ & Roe et al. (2004) \\
\hline & Industrial gas combustion & 51.30 & $\mathrm{~kg}\left(10^{6} \mathrm{~m}^{3}\right)^{-1}$ & Roe et al. (2004) \\
\hline & Domestic gas combustion & 320.51 & $\mathrm{~kg}\left(10^{6} \mathrm{~m}^{3}\right)^{-1}$ & Sutton et al. (2000) \\
\hline $\begin{array}{l}\text { Urban } \\
\text { landcover }\end{array}$ & Green land & 6.10 & $\mathrm{kgha}^{-1} \mathrm{yr}^{-1}$ & $\begin{array}{l}\text { Sutton et al. (2000), } \\
\text { Zhang (2002) }\end{array}$ \\
\hline \multirow[t]{2}{*}{ Pets } & Dogs & 0.74 & $\mathrm{kganimal}^{-1} \mathrm{yr}^{-1}$ & Sutton et al. (2000) \\
\hline & Cats & 0.13 & $\mathrm{kganimal}^{-1} \mathrm{yr}^{-1}$ & Sutton et al. (2000) \\
\hline \multirow{2}{*}{$\begin{array}{l}\text { Domestic } \\
\text { activity }\end{array}$} & Household products & 17.10 & gperson $^{-1} \mathrm{yr}^{-1}$ & Roe et al. (2004) \\
\hline & Non-agricultural fertilizers & 36.90 & gperson $^{-1} \mathrm{yr}^{-1}$ & Roe et al. (2004) \\
\hline
\end{tabular}

Non-agricultural ammonia emissions

in urban China

Y. H. Chang

\section{Title Page}

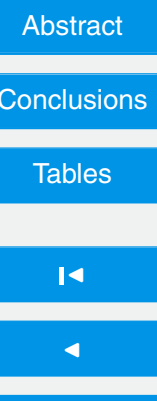

Back

Introduction

References

Figures

$>1$

$>$

\section{Close}

\section{Full Screen / Esc}

Printer-friendly Version

Interactive Discussion 
Table 2. Summary of non-agricultural ammonia estimates (in Mg) by city in $2010^{*}$.

\begin{tabular}{|c|c|c|c|c|c|c|c|c|}
\hline City & TR & WD & $\mathrm{HM}$ & PE & $\mathrm{FC}$ & $\mathrm{GL}$ & $\mathrm{HH}$ & Total \\
\hline Beijing & 4909.7 & 4013.6 & 313.5 & 1152.9 & 2257.1 & 376.3 & 200.9 & 13224.0 \\
\hline Tianjin & 1817.7 & 966.8 & 214.4 & 788.1 & 1264.6 & 106.0 & 137.3 & 5294.7 \\
\hline Shijiazhuang & 790.3 & 368.4 & 65.4 & 238.3 & 1117.5 & 50.2 & 41.5 & 2671.6 \\
\hline Tangshan & 1038.1 & 483.9 & 82.7 & 301.3 & 2012.5 & 53.3 & 52.5 & 4024.2 \\
\hline Qinhuangdao & 216.1 & 100.7 & 26.7 & 81.1 & 482.7 & 25.2 & 14.1 & 946.6 \\
\hline Handan & 548.7 & 255.7 & 47.7 & 144.7 & 539.6 & 37.2 & 25.2 & 1598.8 \\
\hline Baoding & 476.2 & 221.9 & 34.4 & 104.3 & 500.4 & 27.2 & 18.2 & 1382.6 \\
\hline Taiyuan & 714.0 & 272.6 & 89.5 & 279.9 & 2026.8 & 47.0 & 48.8 & 3478.6 \\
\hline Datong & 105.0 & 40.9 & 48.6 & 151.8 & 300.3 & 24.0 & 26.5 & 697.0 \\
\hline Yangquan & 115.7 & 45.1 & 21.6 & 67.5 & 375.6 & 11.0 & 11.8 & 3 \\
\hline Changzhi & 108.4 & 42.3 & 21.9 & 68.5 & 317.9 & 12.3 & 11.9 & 583.3 \\
\hline Linfen & 85.2 & 33.2 & 26.1 & 81.8 & 288.8 & 7.3 & 14.2 & 536.6 \\
\hline Hohhot & 436.7 & 292.7 & 36.6 & 116.6 & 2002.4 & 16.1 & 20.3 & 2921.4 \\
\hline Baotou & 576.1 & 386.2 & 43.5 & 138.9 & 3093.4 & 43.0 & 24.2 & 4305.2 \\
\hline Chifeng & 254.4 & 170.6 & 37.4 & 119.2 & 636.9 & 15.5 & 20.8 & 1254.8 \\
\hline Shenyang & 1127.0 & 1057.8 & 149.2 & 502.8 & 1446.9 & 158.6 & 87.6 & 4529.9 \\
\hline Dalian & 1158.5 & 1087.4 & 88.0 & 296.4 & 1236.2 & 74.4 & 51.6 & 3992.5 \\
\hline Anshan & 469.3 & 447.8 & 42.9 & 144.5 & 439.5 & 34.1 & 25.2 & 1603.3 \\
\hline Fushun & 197.7 & 188.7 & 40.5 & 136.5 & 229.0 & 27.3 & 23.8 & 843.3 \\
\hline Benxi & 190.0 & 181.3 & 27.8 & 93.8 & 207.4 & 29.1 & 16.3 & 745.8 \\
\hline Jinzhou & 201.5 & 192.2 & 27.2 & 91.7 & 160.7 & 15.8 & 16.0 & 705.1 \\
\hline Changchun & 853.1 & 469.6 & 106.6 & 355.6 & 993.2 & 70.6 & 62.0 & 2910.7 \\
\hline Jilin & 461.3 & 253.9 & 54.5 & 181.7 & 399.5 & 39.7 & 31.6 & 1422.1 \\
\hline Harbin & 964.2 & 620.8 & 141.4 & 46 & 1300.6 & 74.3 & 81.2 & 3648.4 \\
\hline Qiqihar & 231.6 & 149.1 & 42.3 & 139.4 & 200.4 & 29.8 & 24.3 & 816.8 \\
\hline Mudanjiang & 201.3 & 129.6 & 23.8 & 78.4 & 115.1 & 30.9 & 13.7 & 592.8 \\
\hline Shanghai & 1581.4 & 3369.3 & 404.0 & 1307.1 & 3139.6 & 713.3 & 227.7 & 10742.4 \\
\hline Nanjing & 1056.7 & 545.1 & 168.0 & 535.9 & 1344.7 & 471.1 & 93.4 & 4214.9 \\
\hline Wuxi & 1192.3 & 615.1 & 73.3 & 233.7 & 317.3 & 101.0 & 40.7 & 2573.4 \\
\hline Xuzhou & 605.5 & 312.4 & 57.3 & 182.8 & 137.9 & 63.6 & 31.8 & 1391.3 \\
\hline Changzhou & 116.2 & 247.6 & 69.7 & 222.5 & 243.4 & 41.3 & 38.8 & 979.6 \\
\hline Suzhou & 1900.2 & 980.3 & 73.9 & 235.8 & 354.3 & 79.3 & 41.1 & 3664.8 \\
\hline
\end{tabular}

ACPD

14, 8495-8531, 2014

Non-agricultural ammonia emissions

in urban China

Y. H. Chang

\section{Title Page}

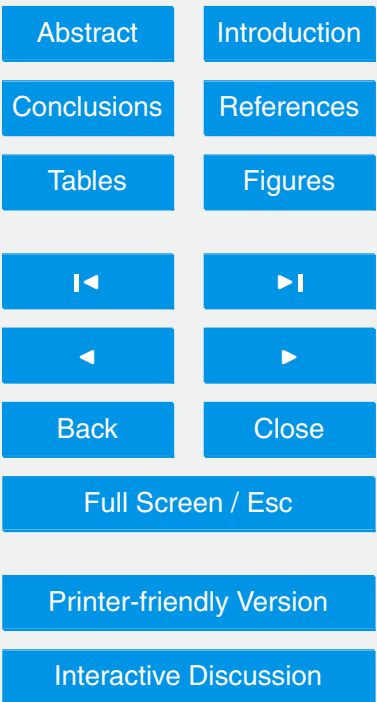


Table 2. Continued.

\begin{tabular}{|c|c|c|c|c|c|c|c|c|}
\hline City & TR & WD & $\mathrm{HM}$ & $\mathrm{PE}$ & FC & $\mathrm{GL}$ & $\mathrm{HH}$ & Total \\
\hline Nantong & 713.8 & 368.3 & 65.1 & 207.6 & 134.8 & 23.2 & 36.2 & 1549.0 \\
\hline Lianyungang & 245.6 & 126.7 & 27.3 & 87.1 & 46.8 & 22.0 & 15.2 & 570.6 \\
\hline Yangzhou & 458.8 & 236.7 & 37.5 & 119.7 & 95.3 & 20.9 & 20.9 & 989.8 \\
\hline Zhenjiang & 398.7 & 211.2 & 31.8 & 101.5 & 96.7 & 39.0 & 17.7 & 896.7 \\
\hline Hangzhou & 1784.2 & 899.8 & 133.5 & 42 & 506.7 & 95.7 & 73.4 & 35 \\
\hline Ningbo & 1548.0 & 780.7 & 68.9 & 217.7 & 330.5 & 52.6 & 37.9 & 3036.5 \\
\hline Wenzhou & 877.1 & 442.3 & 45.0 & 142.1 & 145.6 & 20.8 & 24.8 & 1697.7 \\
\hline Huzhou & 390.8 & 197.1 & 33.7 & 106.6 & 62.7 & 20.5 & 18.6 & 829.9 \\
\hline Shaoxing & 838.0 & 422.6 & 20.2 & 63.7 & 74.1 & 21.1 & 11.1 & 1450.9 \\
\hline Hefei & 665.0 & 360.3 & 67.6 & 204.7 & 818.3 & 64.3 & 35.7 & 2216.0 \\
\hline Wuhu & 27 & 147.9 & 34.0 & 103.0 & 34 & 30.4 & 17.9 & \\
\hline Maanshan & 195 & 108.1 & 20.6 & 62.4 & 26 & 29.6 & 10.9 & 3 \\
\hline Fuz & 3 & 393.8 & 60.0 & .9 & 231.8 & 46.5 & 32.0 & 1624.2 \\
\hline & 446 & 25 & 56.7 & 7 & 28 & 87.3 & 30.3 & 6.9 \\
\hline Quanzhou & 772.0 & 449.5 & 33.0 & 101.0 & 118.7 & 19.7 & 17.6 & \\
\hline Nanchang & 467.4 & 354.3 & 73.0 & 218.4 & 311.2 & 45.3 & 38.0 & 1507.6 \\
\hline Jiujiang & 21 & 165.7 & 20.9 & 62.6 & 92.2 & 24.4 & 10.9 & \\
\hline Ji'n & 109 & 508.6 & 110.7 & 341.8 & 771.3 & 66.9 & 59.5 & 2948.9 \\
\hline Qingdao & 158 & 737.4 & & 270.4 & 860.8 & 97.6 & 47.1 & 36 \\
\hline Zibo & 799.5 & 373.0 & 88.6 & 273.6 & 610.4 & 89.8 & 47.7 & $22 \varepsilon$ \\
\hline Zaozhuang & 1 & 177.3 & 69.8 & 215.5 & 202.9 & 22.5 & 37.5 & 5.7 \\
\hline Yantai & 1234.2 & 575.9 & 57.0 & 175.9 & 468.2 & 55.1 & 30.7 & 2597.0 \\
\hline Weifang & 861.8 & 402.1 & 57.6 & 177.9 & 224.3 & 47.0 & 31.0 & 1801.7 \\
\hline Jining & 708.9 & 330.7 & 38.0 & 117.4 & 164.3 & 27.1 & 20.5 & 1406.9 \\
\hline Taia & 572.3 & 267.0 & 50.6 & 156.3 & 178.2 & 23.8 & 27.2 & 1275.5 \\
\hline Rizhao & & 133.5 & 39.0 & 120.6 & 200.0 & 18.4 & 21.0 & 818.7 \\
\hline Zhengzhou & 1037.8 & 592.5 & 90.2 & 279.7 & 637.2 & 62.8 & 48.7 & 2749.0 \\
\hline Kaifeng & 238.4 & 136.1 & 27.0 & 83.8 & 86.0 & 17.1 & 14.6 & 603.1 \\
\hline Luoyang & 596.0 & 340.3 & 50.7 & 157.1 & 287.6 & 30.0 & 27.4 & 1489.0 \\
\hline Pingdingshan & 336.8 & 192.3 & 32.2 & 100.0 & 176.9 & 13.1 & 17.4 & 868.8 \\
\hline Anyang & 338.0 & 193.0 & 34.0 & 105.5 & 167.5 & 14.7 & 18.4 & 871.2 \\
\hline Jiao & 320.2 & 182.8 & 26.4 & 82.0 & 103.1 & 16.9 & 14.3 & 745.8 \\
\hline Sanmenxia & 30.3 & 17.3 & 9.2 & 28.7 & 39.5 & 7.3 & 5.0 & 137.3 \\
\hline
\end{tabular}

Non-agricultural ammonia emissions

in urban China

Y. H. Chang

Title Page

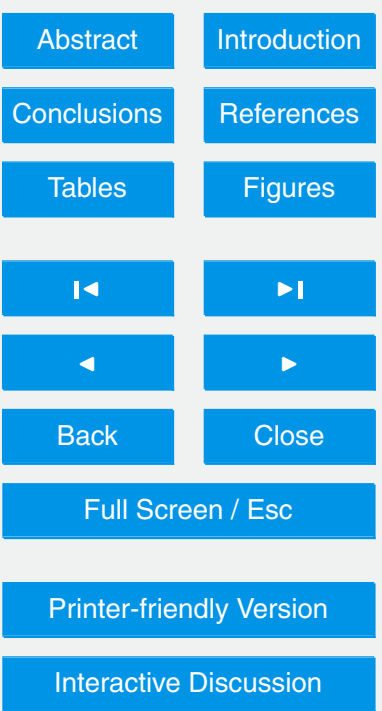


Table 2. Continued.

\begin{tabular}{|c|c|c|c|c|c|c|c|c|}
\hline City & TR & WD & $\mathrm{HM}$ & PE & FC & $\mathrm{GL}$ & $\mathrm{HH}$ & Total \\
\hline Wuhan & 1052.5 & 915.3 & 158.3 & 505.5 & 2536.6 & 93.1 & 88.1 & 5349.2 \\
\hline Yichang & 293.4 & 255.2 & 38.4 & 122.5 & 416.3 & 18.6 & & 1165.6 \\
\hline Jingzhou & 63.4 & 55.1 & 35.9 & 114.7 & 164.6 & 11.3 & 20.0 & 465.0 \\
\hline Changsha & 912.9 & 705.8 & 78.1 & 236.5 & 613.2 & 49.6 & 41.2 & 2637.3 \\
\hline Zhuzhou & 256.0 & 197.9 & 32.5 & 98.4 & 266.0 & 21.1 & 17.1 & 889.0 \\
\hline Xiangtan & 179.4 & 138.7 & 28.4 & 86.1 & 268.6 & 21.3 & 15.0 & \\
\hline Yueyang & 309.1 & 239.0 & 28.4 & 85.9 & 27 & 23.9 & 0 & \\
\hline Char & 295 & 23 & 45.6 & 138.0 & & 17.4 & 24.0 & \\
\hline Zhangjiajie & 48.6 & 37.6 & 16.2 & 49.0 & & 7.9 & 8.5 & \\
\hline zhou & 2840.3 & 1771.5 & 208.3 & 642.6 & 120 & 759.0 & 112.0 & 7538.4 \\
\hline Shaoguan & 179.9 & 112.2 & 29.3 & 90.4 & 45.8 & 18.9 & 15.7 & 492.3 \\
\hline Shenzhen & 2531.5 & 1578.9 & 78.2 & 241.4 & 117 & 587.9 & 42.1 & 6237.5 \\
\hline Zhul & 319 & & 32.7 & 1 & & 31.8 & 17 & \\
\hline She & & & 16 & & & 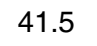 & 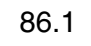 & 2.8 \\
\hline Zha & 370 & 23 & 48 & 0 & & 67.9 & 26.0 & 5.8 \\
\hline & 478.3 & & 88.0 & 262.2 & & 213.1 & 45.7 & 1602.4 \\
\hline Liuz & 34 & 196.7 & 34.2 & 101.9 & & 35.7 & 17.8 & 901.0 \\
\hline Guilin & 293.2 & 16 & 25.0 & 74.4 & & 13.9 & 13.0 & 653.4 \\
\hline Beihai & & & & & & 12.3 & 10.3 & 4.0 \\
\hline & & & & 15 & & 22.0 & & \\
\hline Cho & & & 477.2 & 151 & & 564.0 & 263.8 & 52 \\
\hline Cher & 169 & 10 & 15 & 51 & 27 & 98.4 & 89.1 & 3842.9 \\
\hline Zigong & & 117.9 & 46.0 & 147.8 & & 12.5 & 25.7 & 651.3 \\
\hline Panzhihua & 160.2 & & 21.2 & 67.9 & 147.9 & 12.3 & 11.8 & 516.7 \\
\hline Luzhou & 218.5 & 130.1 & 44.5 & 142.8 & & 17.8 & 24.9 & 671.6 \\
\hline Dey & 281 & 167.6 & 20.2 & & & 11.6 & 113 & 627.0 \\
\hline Mia & 293 & & 37. & 12 & & 21 & 20.9 & 763.6 \\
\hline Nanchong & 253.2 & 150.7 & 59.1 & 189.8 & 54.8 & 18.3 & 33.1 & 758.9 \\
\hline Yibin & 266.3 & 158.5 & 24.5 & 78.6 & 56.3 & 10.7 & 13.7 & 608.5 \\
\hline Guiyang & 390.3 & 283.2 & 71.5 & 214.8 & 1176.4 & 35.1 & 37.4 & 2208.7 \\
\hline Zun & 316.2 & 229.4 & 27.9 & 83.7 & 375.3 & 14.5 & 14.6 & 1061.6 \\
\hline Kun & 1025.1 & 356.4 & 80.5 & 245.6 & 687.7 & 61.2 & 42.8 & 2499.3 \\
\hline Qujing & 486.2 & 157.6 & 22.3 & 68.2 & 128.4 & 19.9 & 11.9 & 894.5 \\
\hline
\end{tabular}

ACPD

14, 8495-8531, 2014

Non-agricultural ammonia emissions

in urban China

Y. H. Chang

\section{Title Page}

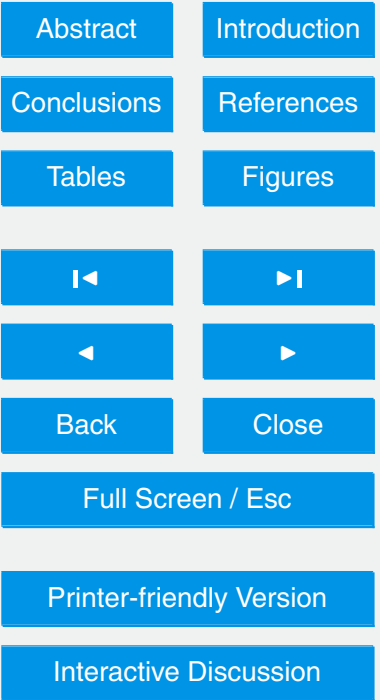




\section{ACPD}

\section{4, 8495-8531, 2014}

\section{Non-agricultural}

Table 2. Continued.

\begin{tabular}{lcccccccc}
\hline City & TR & WD & HM & PE & FC & GL & HH & Total \\
\hline Yuxi & 285.7 & 92.6 & 13.5 & 41.3 & 173.8 & 6.1 & 7.2 & 620.1 \\
Lhasa & 73.3 & 0.0 & 7.3 & 21.3 & 223.8 & 12.6 & 3.7 & 341.8 \\
Xi'an & 904.8 & 547.0 & 174.6 & 551.2 & 1121.9 & 73.6 & 96.0 & 3469.1 \\
Tongchuan & 52.3 & 31.6 & 23.5 & 74.3 & 68.1 & 9.6 & 12.9 & 272.4 \\
Baoji & 272.4 & 164.7 & 44.0 & 138.8 & 217.5 & 20.2 & 24.2 & 881.7 \\
Xianyang & 306.6 & 185.4 & 27.9 & 88.0 & 156.1 & 12.9 & 15.3 & 792.1 \\
Weinan & 223.8 & 135.3 & 30.1 & 95.0 & 67.8 & 8.3 & 16.6 & 576.8 \\
Yan'an & 247.2 & 149.5 & 14.0 & 44.0 & 62.6 & 5.5 & 7.7 & 530.4 \\
Lanzhou & 307.9 & 176.3 & 68.5 & 206.6 & 577.5 & 26.7 & 36.0 & 1399.3 \\
Jinchang & 58.9 & 33.7 & 7.0 & 21.1 & 102.5 & 4.0 & 3.7 & 230.9 \\
Xining & 192.4 & 158.7 & 37.8 & 112.0 & 229.3 & 8.3 & 19.5 & 758.0 \\
Yinchuan & 263.8 & 243.6 & 30.2 & 89.7 & 283.1 & 31.6 & 15.6 & 957.6 \\
Shizuishan & 99.4 & 91.8 & 15.0 & 44.6 & 570.7 & 37.2 & 7.8 & 866.4 \\
Urumqi & 431.5 & 318.1 & 78.4 & 227.6 & 1406.2 & 93.8 & 39.7 & 2595.2 \\
Karamay & 229.2 & 169.0 & 13.3 & 38.6 & 384.5 & 13.4 & 6.7 & 854.7 \\
\hline 113 cities & 67670.8 & 44287.8 & 7312.3 & 23354.6 & 56275.0 & 7508.8 & 4068.7 & 210478.0 \\
\hline
\end{tabular}

* TR, traffic; WD, waste disposal; HM, humans; PE, pets; FC, fuel combustion; GL, green land; $\mathrm{HH}$, household.

\section{ammonia emissions \\ in urban China}

Y. H. Chang

\section{Title Page}

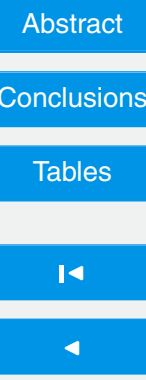

Back

Introduction

References

\section{Figures}

$>1$

$>$

Close

Full Screen / Esc

Printer-friendly Version

Interactive Discussion 


\section{ACPD}

14, 8495-8531, 2014

Non-agricultural ammonia emissions

in urban China

Table 3. Comparison of current work with previous $\mathrm{NH}_{3}$ emissions estimates.

\begin{tabular}{lccccc}
\hline City & Year & $\begin{array}{c}\text { Non-agri } \\
\text { emissions } \\
(\mathrm{Mg})\end{array}$ & $\begin{array}{c}\text { Agri } \\
\text { emissions } \\
(\mathrm{Mg})\end{array}$ & $\begin{array}{c}\text { Non-agri } \\
\text { emission intensity } \\
\left(\mathrm{Mg} \mathrm{km}^{-2} \text { year }^{-1}\right)\end{array}$ & Source \\
\hline Beijing, CN & 2010 & 13224 & & 1.72 & $\begin{array}{c}\text { This study } \\
\text { Beijing, CN }\end{array}$ \\
Shanghai, CN & 2006 & 12800 & 46700 & 1.68 & Huang et al. (2012) \\
Shanghai, CN & 2006 & 10742 & & 2.08 & This study \\
Guangzhou, CN & 2010 & 7539 & 31600 & 2.14 & Fu (2009) \\
Guangzhou, CN & 2006 & 10870 & & 1.96 & This study \\
Nanjing, CN & 2010 & 4215 & & 1.46 & Zheng et al. (2012) \\
Nanjing, CN & 2004 & 4390 & & 0.89 & This study \\
Manchester, UK & 2004 & & & 0.93 & Dong et al. (2009) \\
\hline
\end{tabular}

Y. H. Chang

Title Page

Abstract

Introduction

Conclusions

References

Tables

Figures

14

$\rightarrow 1$

Back

Close

Printer-friendly Version

Interactive Discussion 


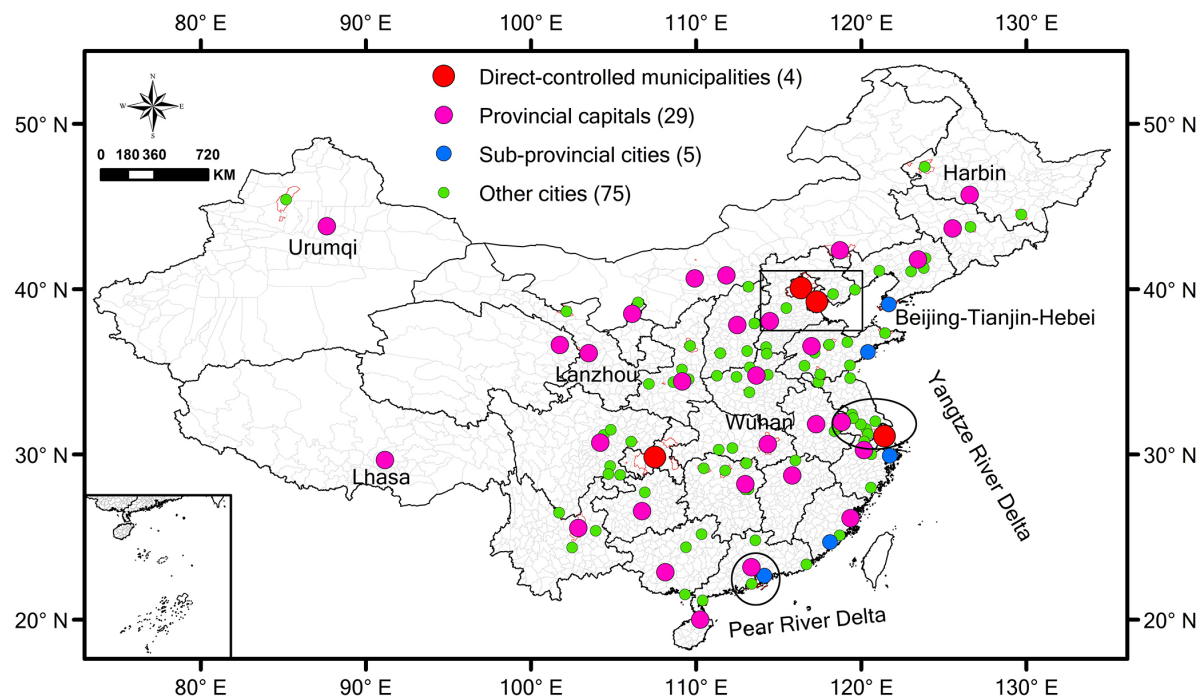

Fig. 1. Distribution of the 113 "key cities" in China and their classification.
ACPD

14, 8495-8531, 2014

Non-agricultural ammonia emissions

in urban China

Y. H. Chang

Title Page

Abstract

Introduction

Conclusions

References

Tables

Figures

14

$\rightarrow 1$

Back

Close

Full Screen / Esc

Printer-friendly Version

Interactive Discussion

c) (1) 


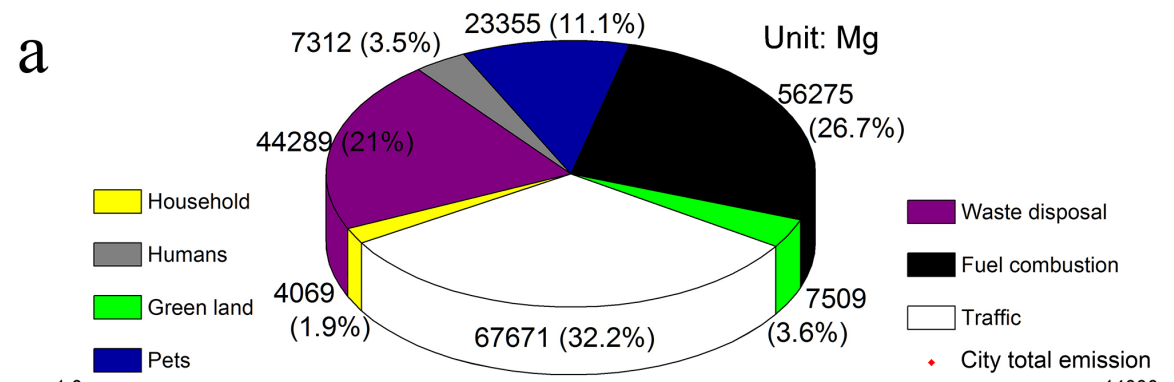

\section{ACPD}

14, 8495-8531, 2014

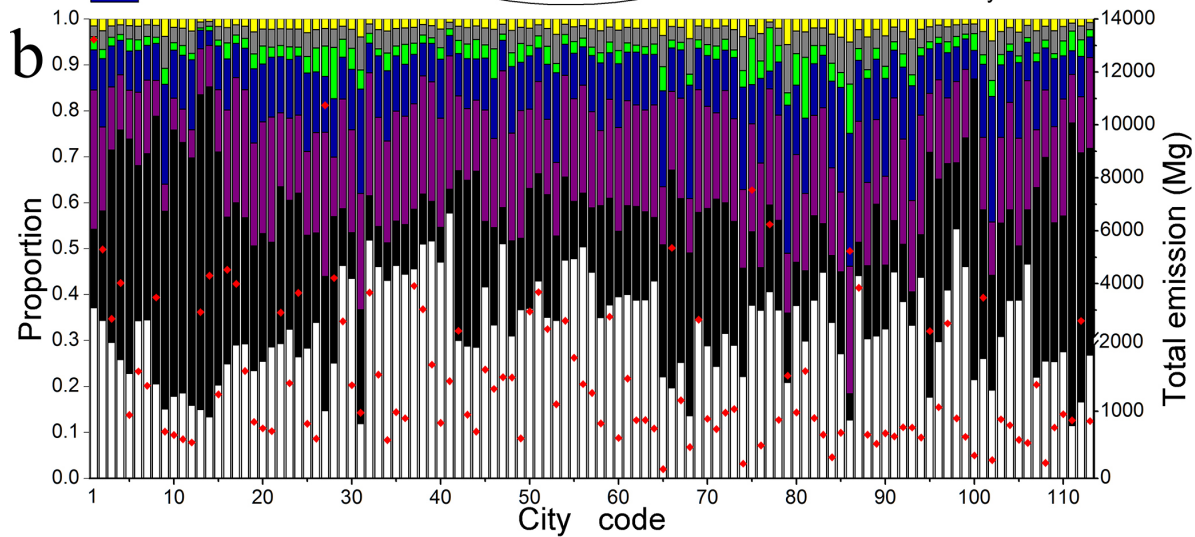

Fig. 2. Pie chart (a) and stack column (b) presenting the source-based non-agricultural $\mathrm{NH}_{3}$ emission contributions of all the 113 cities and each specific city, respectively; $x$-axis (b): every number representing a specific city (see Table S1), right y-axis (b): red dot indicating the total non-agricultural $\mathrm{NH}_{3}$ emissions of each city (set 2000 as the breakpoint), left y-axis (b): stacked histograms showing the variations of contribution sources for each city.

Non-agricultural ammonia emissions

in urban China

Y. H. Chang

\section{Title Page}

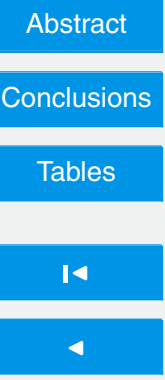

Introduction

References

\section{Figures}

$>1$

Back

Close

Full Screen / Esc

Printer-friendly Version

Interactive Discussion 

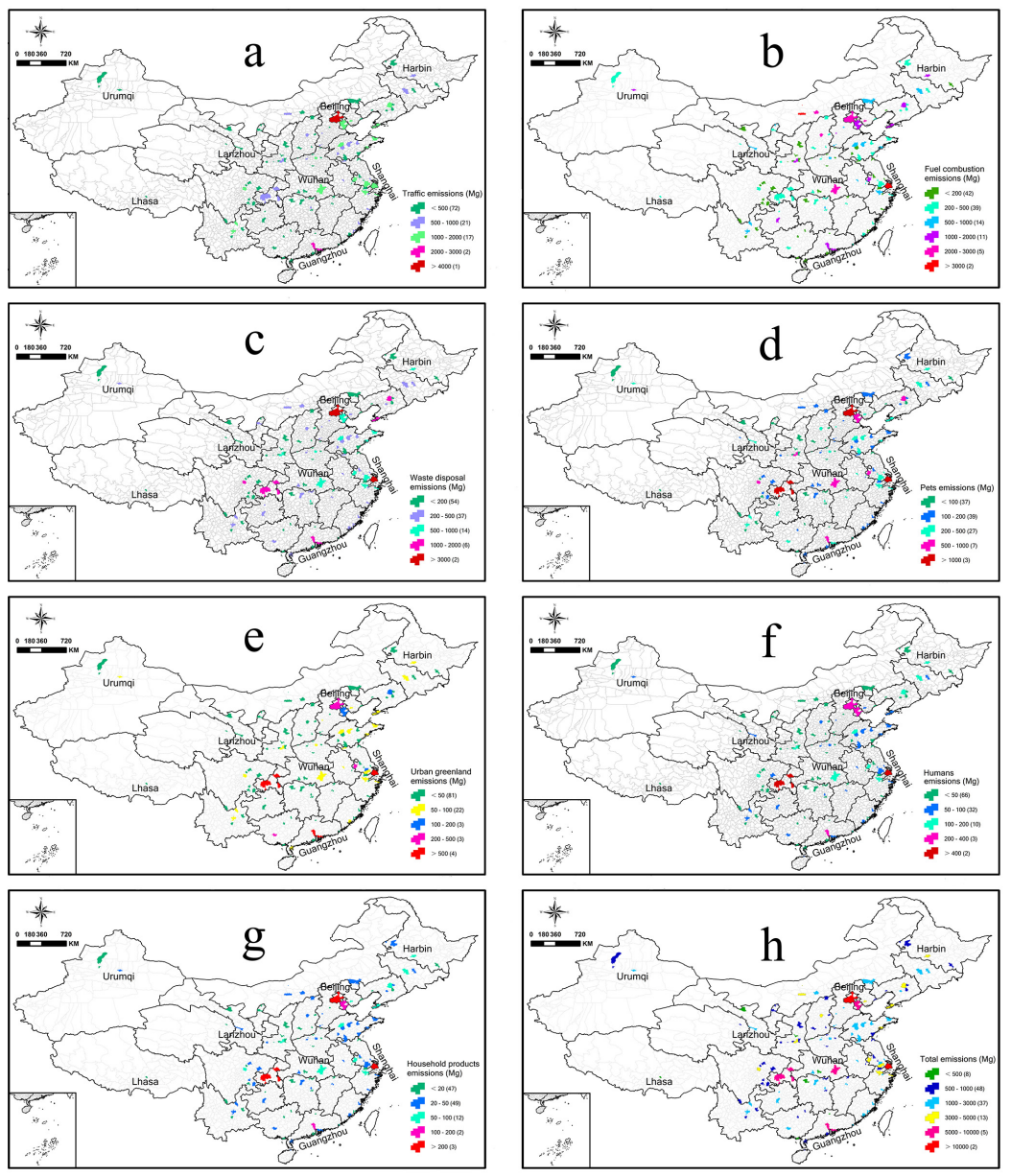

Fig. 3. Spatial distributions of non-agricultural $\mathrm{NH}_{3}$ emissions by source category in China's 113 key cities (figures in brackets represent the number of cities).
ACPD

14, 8495-8531, 2014

Non-agricultural ammonia emissions

in urban China

Y. H. Chang

Title Page

Abstract

Introduction

Conclusions

References

Tables

Figures

14

$>1$

4

Back

\section{Full Screen / Esc}

Printer-friendly Version

Interactive Discussion 


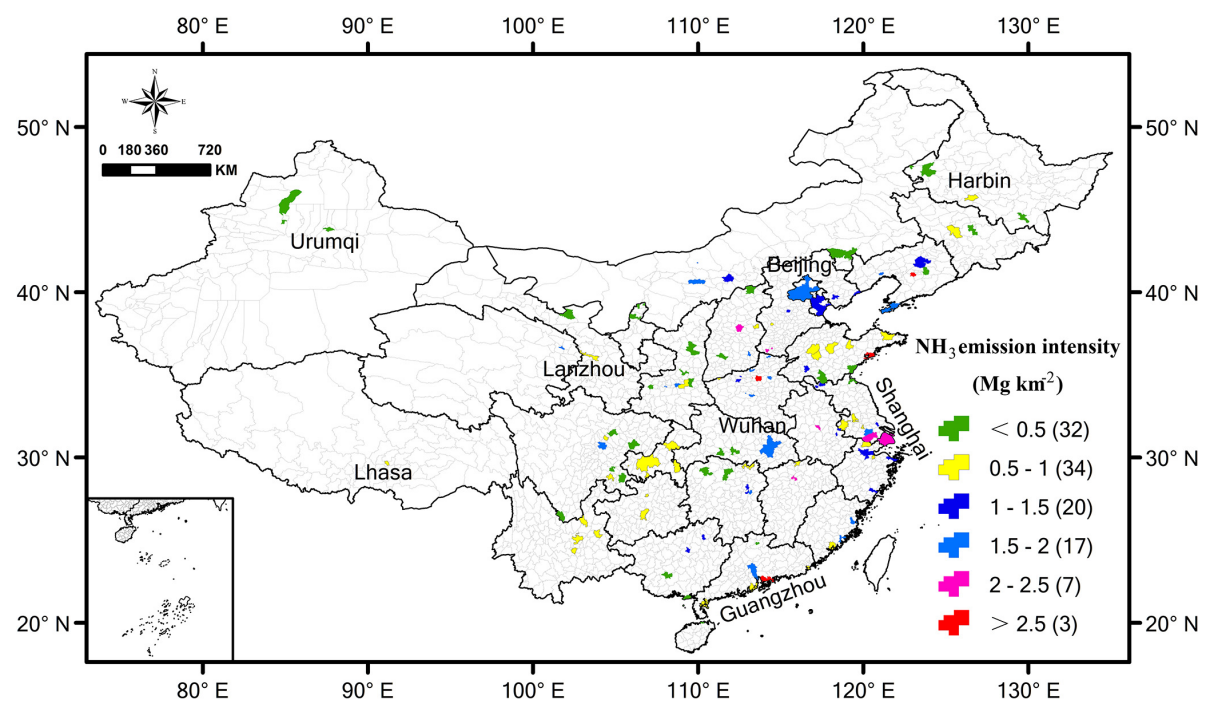

Fig. 4. Spatial patterns of $\mathrm{NH}_{3}$ emission intensities in China's 113 key cities (figures in brackets represent the number of cities).
ACPD

14, 8495-8531, 2014

Non-agricultural ammonia emissions

in urban China

Y. H. Chang

\section{Title Page}

Abstract

Introduction

Conclusions

References

Tables

Figures

14

$\rightarrow 1$

Back

Close

\section{Full Screen / Esc}

Printer-friendly Version

Interactive Discussion 


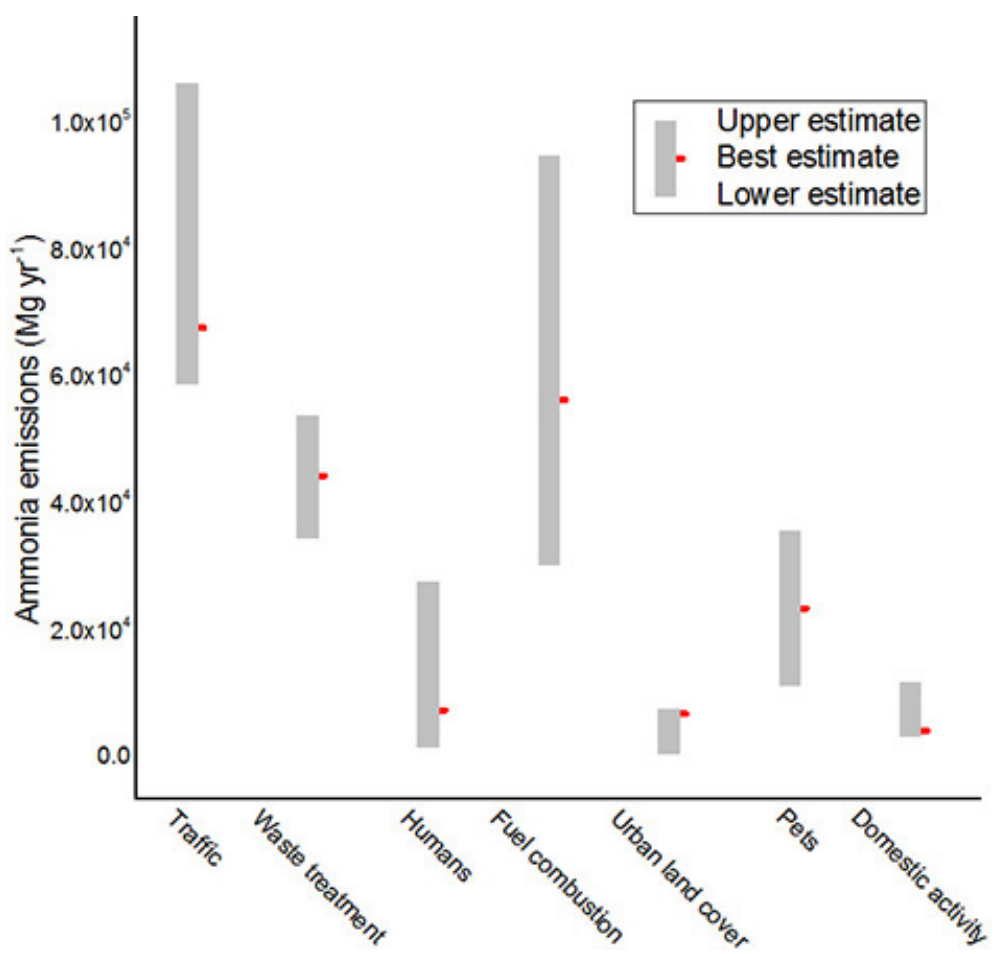

Fig. 5. Uncertainties estimates for the seven non-agricultural ammonia sources of the 113 key cities.

\section{ACPD}

14, 8495-8531, 2014

Non-agricultural ammonia emissions

in urban China

Y. H. Chang

\section{Title Page}

Abstract

Introduction

Conclusions

References

Tables

Figures

14

$\rightarrow 1$

4

Back

$>$

Close

\section{Full Screen / Esc}

Printer-friendly Version

Interactive Discussion 